\title{
Examining the relationship between the literacy coach's support to teachers in the ways of learning to teach reading
}

\author{
Mohlanhledi Makumbila
}

Follow this and additional works at: https://researchrepository.wvu.edu/etd

\section{Recommended Citation}

Makumbila, Mohlanhledi, "Examining the relationship between the literacy coach's support to teachers in the ways of learning to teach reading" (2016). Graduate Theses, Dissertations, and Problem Reports.

6145.

https://researchrepository.wvu.edu/etd/6145

This Dissertation is protected by copyright and/or related rights. It has been brought to you by the The Research Repository @ WVU with permission from the rights-holder(s). You are free to use this Dissertation in any way that is permitted by the copyright and related rights legislation that applies to your use. For other uses you must obtain permission from the rights-holder(s) directly, unless additional rights are indicated by a Creative Commons license in the record and/ or on the work itself. This Dissertation has been accepted for inclusion in WVU Graduate Theses, Dissertations, and Problem Reports collection by an authorized administrator of The Research Repository @ WVU.

For more information, please contact researchrepository@mail.wvu.edu. 
Examining the Relationship between the Literacy Coach's Support to Teachers in the Ways of Learning to Teach Reading.

\author{
Mohlanhledi Makumbila \\ Dissertation prospectus submitted to the \\ College of Education and Human Services \\ At West Virginia University \\ In partial fulfillment of the requirements for the degree of
}

Doctoral of Education

in

Curriculum and Instruction/Literacy Studies

Sharon Hayes, Ph.D.

Patricia Obenauf, Ed.D.

Steven Rinehart, Ed.D.

Joy Saab, Ed.D.

Samuel Stack, Ph.D.

Department of Curriculum and Instruction/Literacy Studies

Morgantown, West Virginia

December 2016

KEYWORDS: Literacy Studies, Reading Instruction, Teacher Learning, Literacy Coach, Professional Development

Copyright: 2016 @ Mohlanhledi Makumbila 


\begin{abstract}
Examining the Relationship between the Literacy Coach's Support to Teachers in the Ways of Learning to Teach Reading.

Mohlanhledi Makumbila
\end{abstract}

The purpose of this study was to examine how an elementary literacy coach supported teachers learning to teach reading in ways that meet the needs of their students. Second, I determined how the coaching influenced the ways in which a classroom teacher plans for and carries out reading instruction. Finally, I understood how the educational context influences the nature of the coaching and how classroom teachers learned to teach reading. The literature review suggests that "when schools function in a way in which staff members have opportunities to interact and talk collegially about issues related to their own, as well as student learning, and are supported by administrators who recognize the importance of collaboration, the school will have quality teaching and learning in both teachers and students involved” (Bean and Swan Dagen, 2012, p. xii). I conducted two interviews per participant and have a total of six interviews. Content analysis was used to analyze the data because it helped in the classification process of coding and identifying themes or patterns of the data.

The findings of this study are presented through the literacy coach and teachers interview's responses; participants’ descriptions of literacy coach supporting teacher learning, and descriptions of teacher learning through the support of literacy coach. My analysis indicated that teachers acknowledged the support provided by the literacy coach on the process of teaching reading. It was also found that the literacy coach used teachers' needs to provide support and planning her professional development. Analysis of the data revealed that teachers learned through the following support (a) the literacy coach came into teachers' classroom, and co-taught 
with them, (b) she modeled lessons while teachers watching the styles of practices, (c) she provided them with the opportunities to practice instruction while they have been observed and got feedback immediately, (d) she helped them to practice new things like the Daily 5 approach, running records, and Being-A-Writer, (e) she provided professional development, (f) she researched relevant literacy resources required by teachers to promote students' reading achievement, (g) she encouraged them to learn from other teachers during the weekly small grade-level groups of professional learning communities, and (h) she influenced them to learn planning instruction through the use of the students' interest. Because of the limitations of this study, the results would not be generalized but the results of the study should be helpful in both literatures because the voices teachers raised will be heard in the discussions of literacy coaches. The perceptions of the literacy coach can also provide insight on the basics of literacy coach discussions that would be most effective in the development of teacher learning and support on their instruction and on students' achievement. 


\section{Dedication}

I want to dedicate this dissertation to my Almighty God who promised to be my shepherd all the time.

To my family, my husband, Mohlaba Makumbila;

To my daughters, Menene, Gabaza Mahlodi, Selamulela Raisibe, Thembi Sefilaro, Mohlaba

Oratilwe(jr); my son, Dlayani Resemate Makumbila, and my late parents, Mr. Longone Samson and Mrs. Maiphehli Raisibe Moyo.

To my mother in-law, Mrs. Shadi Lina Makumbila, who is wishing me good luck every day to complete my program. 


\section{Acknowledgements}

Thanks to my advisor, Dr. Sharon Hayes, chairperson of the dissertation committee, who energetically devoted her precious time to the supervision of this work. I found her suggestions valuable and her criticisms productive. Thank you so much for the encouragement. I would like

to thank Dr. Patricia Obenauf, Dr. Joy Saab, Dr. Steven Rinehart, and Dr. Samuel Stack for their constant professional guidance, support, their patience, and encouragement in this long process. I wish to thank my husband, Mohlaba, Makumbila for his endless support, patience, and encouragement, making it possible for me to complete my doctoral program. Thank you also to my children (Menene, Gabaza, Dlayani, Raisibe, Thembi, and Mohlaba, jr) for supporting and encouraging me on this long process of my doctoral program.

I gratefully thank the elementary school staff for allowing me to carry out the study at their school especially the principal and the assistant principal. My thanks also go to my participants: a literacy coach and two classroom teachers for allowing me to use their time to conduct the interview with them. Finally, I want to thank Dr. Jean Dailey who energetically devoted her precious time to edit this work and provide helpful comments to become a better writer. My vote of thanks also goes to Dr. Regina (Jeannee) McGraw who provided her support and encouraging words throughout the process of the program. My thanks also go to my closest family and friends for the hardship they went through in my absence. To those I have not mentioned here, I want to say thank you so much for your support and encouragement. 


\section{TABLE OF CONTENTS}

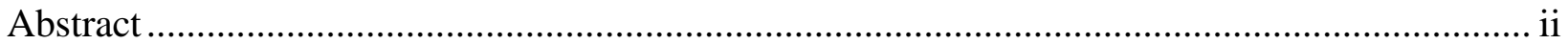

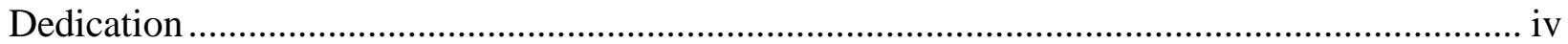

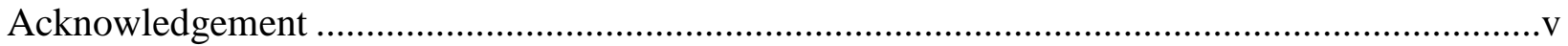

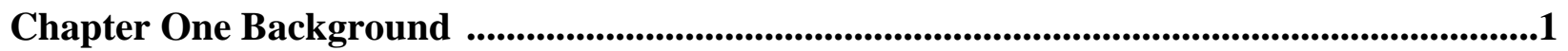

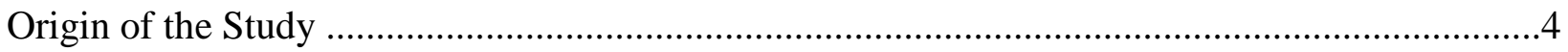

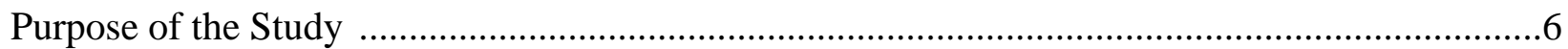

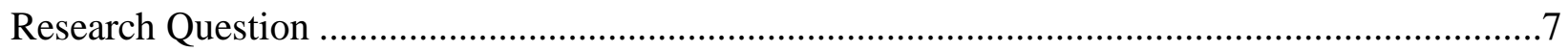

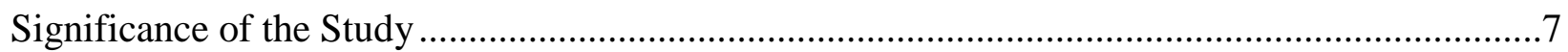

Summary

Chapter Two Review of the Literature ......................................................................................10

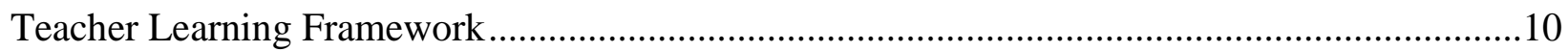

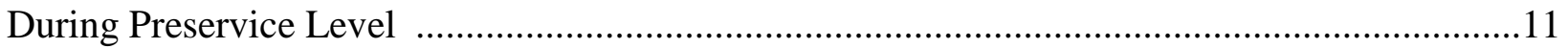

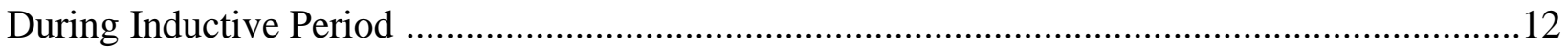

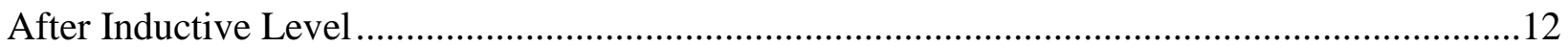

Teacher Learning and Professional Development .....................................................................13

Professional Development .................................................................................................15

Traditional Modeling of Professional Development ……………...............................................17 
Need for Professional Development

Need for Coaching

Models for Coaching .

Benefits for Coaching

Challenges of Coaching

Literacy Coaching

Defining Literacy Coach

Roles and Responsibilities of Literacy Coach

Need for Literacy Coach

Benefits of Literacy Coach

Challenges of Literacy Coach

Summary

Chapter Three Research Methods

Rationale for Qualitative Research

Theoretical Framework of the Study .46

Methods. 
The Research Context

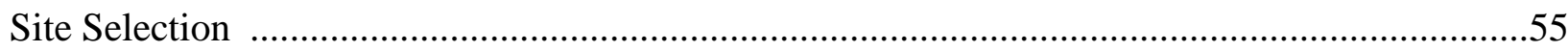

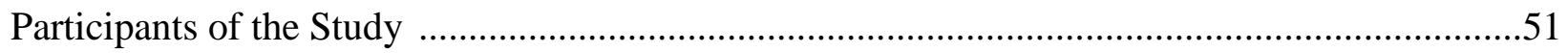

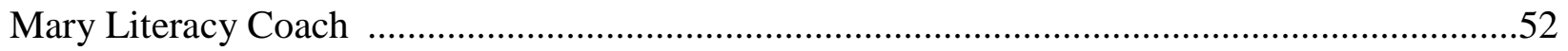

Mary’s Growth as a Teacher and as a Literacy Coach ..........................................................53

Bob’s Learning as an Experience Teacher and Coached by Mary ..........................................53

Nancy’s Learning as a Novice Teacher and Coached by Mary $\quad$...............................................54

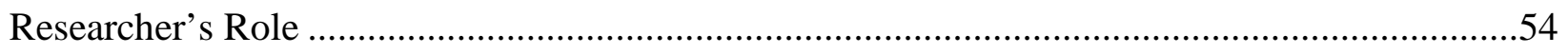

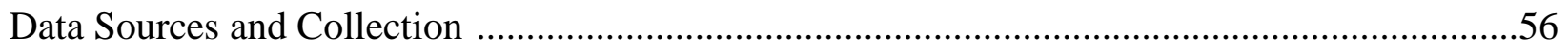

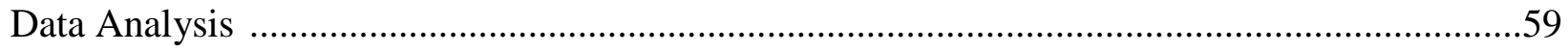

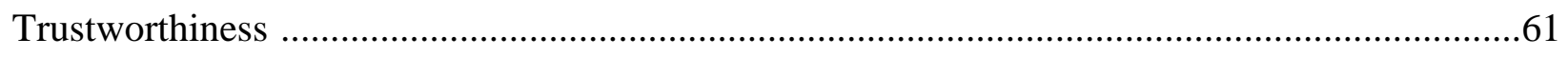

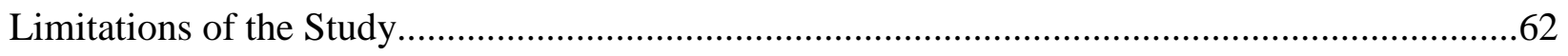

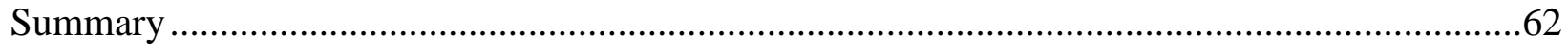

Chapter Four the Findings .......................................................................................................................64

Supporting Collaboration as Described by Mary Literacy Coach ...........................................64

Literacy Coach Describes her Belief in Teacher Learning ....................................................65

Literacy Coach Describes Supporting of Teacher Learning ..................................................66

Supporting Collaboration as Described by Teachers ..........................................................68 
Bob’s Descriptions of the Literacy Coach’s Support of Teacher Learning

Nancy’s Descriptions of the Literacy Coach’s Support of Teacher Learning

Literacy Coaching Influence of Planning and Enacting of Reading Instruction .72

Coaching Influence on Bob’s Planning and on Reading Instruction .74

Coaching Influence on Nancy’s Planning and on Reading Instruction .75

Educational Context Influence on Coaching and on Teacher Learning 77

Summary of Participants .80

Bob (an Experience Teacher) and Nancy (a Novice Teacher) .81

Summary .84

Chapter Five Discussion of Findings

Literacy Coach Support to Teachers . .88

Teachers Explain the Support the Literacy Coach Provides.

Responsibilities of Literacy Coach in this School

How did Two Teachers Learned Teaching Reading. .94

Implications for Literacy Coach’s Support and Teacher Learning .96

Summary and Recommendations for Further Research

References .101

Appendix A: First Interview Questions for Literacy Coach.. 
Appendix B: Second Interview Questions for Literacy Coach.....

Appendix C: First Interview Questions for Teachers

Appendix D: Second Interview Questions for Teachers.

Appendix E: Approval Letter from the School Principal .125

Appendix F: IRB Informed Consent for Literacy Coach.

Appendix G: WVU Acknowledgement Letter Exempt Initial Protocol Review.....

Appendix H: Sample Transcription Interview with the Literacy Coach .128

Appendix I: Sample Transcription Interview with the Teachers

Appendix J: Sample Matrix for Research Questions, Findings and Themes 


\section{Chapter One}

\section{Background}

Far too many children are struggling to read at a level that will allow them to not only excel in their future education and the workplace, but also become good readers for life. The statistics are alarming: in 2008, 23\% of students in the United States did not graduate from high

school, ranking the U.S. near the bottom for developed countries (Ripley, 2008). The research further revealed that "even among students who do graduate from high school, inadequate reading skills are a key obstacle to success in postsecondary education” (Slavin, Chung, Groff, \& Lak, 2008, p. 290).

The problems U.S. students experience when learning to read occur early in their education. National Assessment of Educational Progress (NAEP) data provided evidence that $68 \%$ of third grade students in the United States are ranked below proficiency in reading and comprehension. Buly and Valencia (2002) looked more closely at the scores of students who have scored "below level” on state reading assessments and found that $18 \%$ of the students were categorized as word callers (readers who read the words quickly, but fail to make meaning); $24 \%$ of the students were labeled as slow and steady comprehenders (readers who read slowly, but have strong word identification and comprehension abilities); 18\% of the students were named word stumblers (readers who lack word identification skills, but are able to comprehend texts); $17 \%$ of the students were categorized as slow word callers (readers who lacked fluency and struggle with making meaning of texts); $15 \%$ of the students were categorized as less skilled readers (readers who had difficulty with word identification, but read slowly with great effort); and $9 \%$ of the students cannot read. These statistics are a critical matter for literacy teachers because students' difficulties with reading, if not addressed, are often exacerbated as they move 
from grade level to grade level. Allington (2002) confirmed that when students do not experience reading instruction that addresses their specific needs, students' problems follow them through higher education.

Even though students displayed various patterns of reading performance that influence their poor results on different assessments, Buly and Valencia (2002) contended that "we must remember that below the 'bar’ are individual children with different needs” (p. 235). Heilman, Blair, and Rupley (2002) also reported, "Because children are different in a multitude of ways, there has never been and never will be one simple literacy approach that succeeds equally with all children” (p. 301). Therefore, teachers need to create reading instruction that favors diverse students' experiences, culture, communities, and language (Diller, 1999); as Noguera (2003) suggested, teachers need to make use of "culturally responsive” literacy instruction that would “make learning more appropriate and effective” for students (Gay, 2002 cited in Edwards, McMillon, \& Tuner, 2010, p. 80). Students need to be provided with multiple opportunities to engage in reading and writing, opportunities that value the funds of knowledge students bring with them. Thus, teachers need to create classrooms that (a) provide a literacy-rich environment, good reading models, and integration of language activities; (b) offer students sufficient time to practice and enjoy reading; (c) establish a good relationship between home and school; (d) accommodate students' interests, reading abilities, and styles; (e) make use of various types of instruction and a variety of approaches; (f) activate students' prior knowledge; and (g) put emphasis on constructing, examining, and extending meaning of the texts (Carbo \& Kapinus, 1995, p. 78-79).

Moreover, much research suggested that it is the quality of the teacher that makes a difference in student progress (Dole, 2004; Darling-Hammond, 1999; Allington, 2002; 
Cunningham \& Allington, 2006; Rodgers \& Rodgers, 2004; Reutzel, Robert, \& Cooter, 2012; Snow, Burns, \& Griffin, 1998). Highly qualified teachers have subject knowledge, pedagogical knowledge, and the ability to make a difference in students' achievement (Darling-Hammond, 1999; Goldhaber \& Brewer, 2000; Sanders \& River, 1996). When different approaches to teaching reading were examined, it was the "highly trained and qualified teachers" (Dole, 2004, p. 464) who were the determining factors in the improvements students made in reading: "The teacher was more important than the reading model or program” (Dole, 2004, p. 464). Taylor, Pearson, Peterson, and Rodriquez (2003) report a similar conclusion.

However, to ensure that every student has a highly qualified teacher, teachers need guidance and support in a continuous learning process about the best ways to combine their reading instruction and the teaching in the elementary environment (Collins \& Cheeks, 2000). To further complicate the matter, Feiman-Nemser (2001) affirmed that "if we want schools to produce more powerful learning on the part of students, we had to offer more powerful learning opportunities to teachers" (p. 1014). Bean and Swan Dagen (2012) state that "when schools function in a way in which staff members have opportunities to interact and talk collegially about issues related to their own, as well as student learning, and are supported by administrators who recognize the importance of collaboration, the school will have quality teaching and learning in both teachers and students involved" (p. xii).

In this case, the literacy coach is a key professional player who can assist teachers in addressing the needs of struggling readers or changing teaching practices and/or learning tasks in schools (Sturtevant, 2003). Literacy coaches are defined as "master teachers who provide essential leadership for the school’s overall literacy program, help teachers to create and supervise a long-term staff development program that supports both the development and 
implementation of the literacy program over months and years” (Sturtevant, 2003, p. 1).

Sturtevant further reported that a coach must have a strong knowledge base in literacy and instructional reading strategies that would help him/her to model instructional practices and facilitate teachers' knowledge. Other research indicated that literacy coaches are responsible for working directly with students who have particular difficulties in reading and comprehension, but their major role is to work with content teachers across the curriculum to help them implement and use strategies designed to improve their students' ability to read, write, and succeed in different subjects (Bean, 2004; Sturtevant, 2003; Timperly, Parr, \& Hulsbosch, 2008). To facilitate teacher learning, literacy coaches need to collaborate with teachers, work in their classrooms to model specific strategies and instruction, observe teachers implementing strategies, provide feedback, and facilitate reflective discussions (Moxley \& Taylor, 2006; Vogt \& Shearer, 2007; Bean \& Swan Dagen, 2012; Dole \& Donaldson, 2006; International Reading Association, (IRA), 2006; Blamey, Mayer, \& Walpole, 2008; Bean, 2004). In this way, literacy coaches can provide continuous professional development and follow-up support for teachers as these classroom teachers attempt to develop and implement new teaching strategies in the classrooms in order to promote their students' literacy.

\section{Origin of the Study}

My passion for this study is also informed by my professional experiences teaching for nine years in South Africa. During my tenure as a teacher, I helped students to develop their reading and writing skills by pulling them from their classrooms for 35 minutes a day. I also collaborated with their teachers (grades 2-6) and provided some of the reading instruction that we believed would be useful for the struggling students in their classrooms. After school, I coplanned with these teachers and helped them create learning activities for their students that 
related to the reading lessons. I also wrote students' reports for the school principal and district officials, met with parents once a month to discuss their children's progress, and was involved on the School Assessment Team and Language Art committees. My analysis of students' data provided evidence that they needed a highly knowledgeable teacher if they were to become proficient readers. Through group discussion with my colleagues, I also learned that (a) some of the South African teachers had trouble with teaching reading; (b) some were willing to cooperate and accept support from other teachers; and (c) some were resistant to support from and/or collaboration with others. It seemed that some of my South African colleagues were frustrated when teaching reading and that their students demonstrated limited improvement as readers and remained unmotivated.

As I result, I decided to pursue a Master's degree in the U.S. and become a reading specialist. During my coursework, I learned that the position of reading specialist has shifted and changed over time in response to expanding knowledge and shifts in political priorities (IRA, 2000). In the 1960s, Title 1 teachers were assigned to work mainly one-on-one or in small groups with struggling readers in separate rooms. The instructional content was often different from that taught in the students' regular classrooms, so the most struggling or needy students were expected to adjust to two different classroom environments, approaches, and expectations (Allington \& Walmsley, 1995; Dole, 2004; Quatroche, Bean, \& Hamilton, 2001).

Due to the limited success of pull-out programs for promoting students' literacy, other approaches to helping students develop as readers have been explored. Bean, Grumet, and Bulazo (1999) suggested that the classroom teacher should be the primary source for creating and enacting a developmental reading program in an elementary classroom, integrating the reading specialist as a co-teacher or supplementary instructor. Thus, the roles that a reading 
specialist might take up range from assistant to the classroom teacher, to integrated collaborator (co-planning and co-teaching), to the two teachers working completely independent of one another (Bean, et al., 1999; Dole, 2004; Quatroche, et al., 2001). However, with the emphasis on ensuring that every classroom had a high quality teacher, the role of the reading specialist became that of a mentor and collaborative education consultant (Dole, 2004). Because the research indicated that struggling readers need the best and most qualified teachers (Dole, 2004; Vogt \& Shearer, 2007), I believe that literacy coaches are the best qualified teachers to collaborate with children to help them become proficient readers and also are responsible for support and guidance to teachers, so that the classroom instruction for students is effective.

\section{Purpose of the Study}

Much research has been conducted about the potential of utilizing literacy coaching in teaching and learning environments and the roles and responsibilities of literacy coaches (Dole, 2006; Hasbrouck \& Denton, 2005; Moxley \& Taylor, 2006; IRA, 2006; Bean, Swan Dagen, 2012; Bean, Swan Dagen, \& Knaup, 2003; Furguson, 2010; Walpole \& Blamey, 2008); however, there is a lack of research related to how literacy coaches might support teachers in improving their reading instruction to meet the needs of all learners (Dole \& Donaldson, 2006; IRA, 2006; Deussen \& Buly, 2006; Vogt \& Shearer, 2007).

Therefore, the purpose of this study was threefold. First, I wanted to understand how an elementary literacy coach supports (or does not support) teachers as they learn to teach reading in ways that meet the needs of their students. Second, I wanted to determine how the coaching influences the ways in which a classroom teacher plans for and carries out reading instruction. Finally, I wanted to understand how the educational context influences the nature of the coaching and how classroom teachers learn to teach reading. 


\section{Research Questions}

I framed this study within a constructionist perspective because the knowledge produced is a product of social processes, in which all understandings and statements about what is true are situated within particular communities and are always subject to other interpretations (Gergen, 1994). This perspective allowed me to reflect upon and reconsider the traditional meanings and understandings of literacy coaching and provided a foundation for considering new interpretations and constructing new, possibly more appropriate, situated meanings. Accordingly, the following questions guided my research:

1. How do elementary literacy coach support (or does not support) teachers as they learn to teach reading in ways that meet the needs of their students?

2. How does the coaching influence the ways in which a classroom teacher plans for and carries out reading instruction?

3. How does the educational context influence the nature of the coaching and the ways in which classroom teachers learn to teach reading?

\section{Significance of the Study}

Although research indicated there is a significant increase in the number of literacy coaches in schools today, there is a lack of research on how literacy coaches support teachers to improve their reading instruction in the classrooms (Dole \& Donaldson, 2006; IRA, 2006;

Deussen \& Buly, 2006; Vogt \& Shearer, 2007). With this study, I explored how literacy coaches provided opportunities for professional development to teachers who wish to improve their reading instruction in order to ensure all students become proficient readers. Therefore, the findings of this study helped to provide insights into coaching approaches that work to provide professional learning/development for particular classroom teachers in particular contexts. I also 
learned how the coaching influences teachers' literacy instruction, as well as how the macro and micro contexts influenced the possibilities for learning about and enacting practices that encouraged the development of students’ literacy. In addition, policy makers at the national, state, and local level might make use of the findings to make decisions about how to promote student achievement in reading and to provide authentic professional development for teachers of reading.

Finally, some Sub-Saharan African countries, including South Africa, are using literacy coaches to support classroom teachers as they help their students develop the knowledge, skills, and dispositions they need to be literate. Currently, the Read Educational Trust, enacted coaching as a holistic reform effort that improve teachers’ practices and reasoning the reading achievement of children in both their mother tongue as well as in English (Sailors, Hoffman, Pearson, Beretvas, \& Matthee, 2007/2010). Therefore, I believed that I was able to transfer and implement the understandings I gained from this study to the South African School Wide Literacy Action Plan and help teachers and principals improve content area literacy instruction and interventions with struggling readers.

\section{Summary}

My personal experiences, as well as my reading of the research related to literacy coaching, provided the basis for my interest in pursuing this study. This chapter introduced the study. The research problem was presented as developing from a historical background including the social context. A brief overview of the body of research on literacy coaches indicated the need and significance of the study. The purpose statement and research questions focused the study and helped define the study's limits. Chapter 2 includes a review of related literature 
regarding how teachers learn across the continuum of their careers. In Chapter 3, I describe the methodology of the study. 


\section{Chapter Two}

\section{Review of the Literature}

Linda Darling-Hammond (1999) asserted that “a more complex, knowledge-based and multicultural society is creating new expectations for teachers. Teachers will need to know their subject matter deeply and understand how students think in order to create experiences that actually work to produce learning...we must transform instruction to ensure achievement” (p. 2). If teachers are going to be able to create experiences that result in "more powerful learning on the part of students, then there will need to be opportunities to teachers” (Feiman-Nemser, 2001, p. x). Therefore, Feiman-Nemser (2001) proposes a framework for thinking about a curriculum for teacher learning over time, that includes approaches to teacher preparation, induction, and professional development balanced with the challenges of learning to teach in reform-minded ways. She posits that conventional programs of teacher education and professional development are not designed to promote complex learning by teachers or students, and she suggests that teacher learning and development occur on a professional learning continuum that starts during the teacher preparation program and continues throughout teachers’ careers.

\section{Teacher Learning Framework}

According to Feiman-Nemser (2001), teacher learning responsibilities include: increasing subject matter knowledge, increasing understanding of students and their learning, increasing the tools to study teaching, and increasing self-identify while some knowledge is best gained through university coursework and in the contexts of practices. It also includes facilitating classroom discussion, building on students' knowledge, and enacting a beginning repertoire of teaching that involves being familiar with various curricula materials, instruction, models of teaching, learning 
from others, and types of assessments. Therefore, teachers need to know many things during the process of learning to teach (Feiman-Nemser, 2001).

\section{During Preservice Stage}

Teacher learning begins when prospective teachers enroll in teacher education programs to prepare for their initial certificate. According to Kennedy (1991), preservice teachers need "an understanding of subject matter that is more explicit and deeper than the subject matter knowledge needed by other practitioners... but not only to understand the content deeply, but also to know how that content is taught and learned” (p. 17). Feiman-Nemser (2001) asserts that preservice teachers need to develop and enact a beginning repertoire of teaching that involves being familiar with various curricular materials, models of teaching, and types of assessment. From understanding the subject matter, students, and their needs in the community, it helps to lead to a set of practices that incorporate "a variety of instructional activities to promote student learning” (Hammerness, Darling-Hammond, Bransford, Berliner, Cochran-Smith, McDonald, \& Zeichner, 2005, p. 387). To develop their skills that promote student learning, preservice teachers need to be able to learn to observe, listen, and interpret how other teachers approach similar instruction/topics that influence their students. They need to learn how to analyze student progress or results, and compare different curricular materials that will help to promote student learning. This is the first stage of a teacher education program. 


\section{During Induction Period}

When entering the classroom, preservice teachers need to develop understanding of and flexibility in good teaching approaches. The teacher has responsibility for planning and delivering instruction to students independently. During this phase, most teachers use their knowledge of content and particular students to "make a decision of what and how to teach, and then make a response to what happens” (p. 1028). To achieve their skills, teachers need to understand the teaching styles of how to meet the needs of all the students and of classroom management. Prospective teachers need to get support with emphasis on professional studies that includes student teaching, a peer socialization process used in a variety of professions. FeimanNemser also found that engaging in professional discourse with like-minded colleagues, helps teachers to deepen knowledge of subject matter and curriculum that is grounded in the content and tasks of teaching and learning. In addition, during the process of learning to teach, individual teachers can use different strategies such as working with student/faculty associates and wellqualified mentors; sharing ideas with other teachers about their teaching styles; asking for help from experienced teachers; discussing students’ work and problems they experience; and considering the solution and actions of good teaching. On the other side, beginning teachers get support from highly qualified mentors.

\section{After Inductive Stage}

In their seventh year of teaching, teachers have gained confidence through experience, through the use of student feedback to develop their skills, and through linking their learning and growth to that of their students. In addition, teachers learn through collaboration in on-going professional development seminars, study teams, and peer coaching with the assurance of their 
teaching approaches and of their self-esteem. Most teachers develop instructional practices by learning what to expect from their students

\section{Teacher Learning and Professional Development}

The process of learning to teach is a long, complex, and criticized journey both inside and outside the field. It is a process that is not complete when teachers graduate from teacher education programs and begin their teaching careers. In addition to Feiman-Nemser's debate, Cochran-Smith (2003) states that as teachers enter graduate school, they often make the transition to the role of teacher education with little formal support from the university institution for continuing development.

Research also indicates that teachers can learn from their teaching, from designing programs, from different assessments written, and from an interdisciplinary presentation performed publically (Whitford, Rescoe, \& Fickel cited in Feiman-Nemser, 2001). On the other hand, the learning process starts from experiences in elementary and high school because preservice teachers picture their previous elementary and high school teachers' subject matters, teaching approaches, styles, and instruction they used and evaluate them during their own teacher preparation. The research indicates that the process also does not have any guarantee to invest knowledge to students because major courses find it difficult to explain fundamental concepts in learning development (Feiman-Nemser, 2001; Grossman, Hammerness, \& McDonald, 2009; Kennedy, 1991; Cochran-Smith, 2003).

In the 1990s, teacher learning shifted to multiple professional development opportunities where learning occurs with professional development that provides teachers with more opportunities to learn teaching (Feiman-Nemser, 2001). Research explained that certain types of 
college educational experiences such as college courses or in-service workshops can make a difference in the learning process of teaching, especially when teachers are given opportunities to reason or debate about the subject matter as a group (Kennedy, 1991; Darling-Hammond, 1999). Similar to those researchers, Grossman, Hammerness, and McDonald (2009) view that "practice incorporates both the technical and the intellectual, and is enacted not by single individuals, but as members of a broader community of practice” (p. 275). Making these practices known establishes a sense of collaboration and community between teachers within the setting. This action serves to perpetuate and further develop the established pedagogy and look to improve practice. A community practice seeks to locate the learning in the process of co-participation (building social capital) and not just within individuals.

Teacher learning through practicing community was found to be a central element, one of great importance when learning to teach. The approach found that it is important for improving outcomes for students and improving teacher practice through the shared learning and collective development of the community members (Fullan, 1993). Some researchers viewed teacher learning as a way to change the perception of preservice teachers and provide them with the opportunity to examine themselves and their attitudes towards students, community background, and their needs (Grossman, et al., 2009; Zeichner, 2012; Cooper, 2007). Community-practice learning also allows teachers to connect instruction with the knowledge and learning process that children bring from their homes. In addition, Zeichner and Melnick (1996) state that incorporating knowledge of community-practice in teacher learning will help prospective teachers to start learning to see the students not as isolated individuals in the classrooms but as members of a larger community. This helps teachers present their curriculum and instruction effectively by involving the parents and the communities in their children's education 
To summarize, teacher learning might be the cornerstone of school reform and might took shape in many ways, from teacher education with preservice teachers to in-service education with experienced teachers. The literature indicated that teacher learning should incorporate theory and practice because teachers are the most critical element in student achievement. For example, most teachers had tracked students’ progress as content that was learned to make them successful with subject matter. More specifically, they focused on learning goals, attended to the integrity of the subject matter, managed individual student behavior and maintained a productive learning environment, posed strategic target questions, interpreted students' work, crafted responses, and assessed and steered all of this toward each student's growth (Ball \& Forzani, 2009). Therefore, teachers need opportunities for professional discourse, problem-solving, and active learning. When the work is carried out, teachers need to be provided with opportunities to share or discuss collaboratively to create a high quality culture of teaching and learning.

\section{Professional Development}

One goal of our educational system is to increase students' achievement by addressing the needs of all students and moving them from where they are to a higher level of academic performance through providing teachers with more opportunities for professional development (Desimone, Porter, Garet, Yoon, \& Berman, 2002; Taylor, Pearson, \& Rodriguez, 2005; National Institute of Child Health and Human Development, 2000; Borko, 2004). Therefore, professional development is understood and described in different ways. DuFour, Eaker, and DuFour (2006), for example, defined professional development as "a lifelong collaborative learning process that nourishes the growth of individuals, teams, and the school through a daily job-embedded, learner-centered, focused approach” (p.217). In addition, Feiman-Nemser (2001) described 
professional development more specifically as a process that (a) takes place through serious, ongoing conversation; (b) focuses on the particulars of teaching, learning, subject matter, and students; and (c) includes engagement in professional discourse with like-minded colleagues grounded in the content and tasks of teaching and learning, allowing teachers to deepen their knowledge of subject matter and curriculum, refine their instructional repertoire, enhance their inquiry skills, and become critical colleagues. She posits professional development as a way that changes “teachers' knowledge, understanding, skills, and commitments, in what they know and what they are able to do in their individual practice as well as in their shared responsibilities” (p. 1038). Guskey (2000) described professional development as "those processes and activities designed to enhance the professional knowledge, skills, and attitude of educators so that they might, in turn, improve the learning of students” (p. 16). Fullan (1995) also defined professional development as "the sum total of formal and informal learning pursued and experienced by the teacher in a compelling learning environment under conditions of complexity and dynamic changes” (p. 265). Generally, Day’s (1999) definition perhaps best highlights teachers’ continuous professional learning within the broader context of change and its interconnected elements. According to Day,

Professional development consists of all natural learning experiences and those conscious and planned activities which are intended to be of direct or indirect benefit to the individual, group or school, which constitute, through these, to the quality of education in the classroom. It is the process by which, alone and with the moral purposes of teaching; and by which they acquire and develop critically the knowledge... Skills and emotional intelligence essential to good professional thinking, planning and practice with children, young people and colleagues throughout each phase of their teaching (p. 27). 


\section{Traditional Models of Professional Development}

Not surprisingly, professional development for teachers often included in more than one model. Mertler (2005) states that traditional professional development sessions were “a gathering of teachers, usually after a long day of teaching or on a jam-packed workshop day, who sit and listen to an expert describe a new methodology, approach, or instructional material that they typically do not believe relate directly to their classroom situation or teaching” (p. 15). Traditional staff development offered teachers little or no choice of topics. Districts assumed that to some extent, teachers will implement any new approaches presented. Workshops or in-service training were usually held during summer break, after school, or on a few staff development days during the school year. These meetings were sometimes conducted by outside consultants who came in for a short time and sometimes offered little follow-up consultation to teachers. According to Fullan (1991), the information that is introduced to teachers during the sessions such as these was difficult for teachers to implement because there was no support or immediate feedback provided to help improve their teaching and learning. Gall and Renchler (1985) categorized professional development as compensating for a lack in skills or knowledge and viewing teachers as empty vessels “to be filled” (Gamston, 1991, p. 64). Some positioned it within an "educational change” model, which views development as more self-directed, arising from the learner's interests and needs (Feiman-Nemser, 2001).

Kelleher (2003) stated that traditional professional development activities may not be connected to a particular school or district goal and often have no follow-up. It was also described as an activity that tends to amount to a series of disjointed experiences that do not necessarily have any observable effect on education. "And there is no easy way to measure what programs or pursuits will lead to changes in students learning” (p. 751). Therefore, professional 
development was viewed as ineffective to teachers’ practices (Kelleher, 2003; Ball \& Cohen, 1999; Joyce \& Showers, 2002) because the goal was to accomplish high quality instruction by using an effective professional development system. The system can provide teachers with research-based practices and assistance of the literacy coach to help master new methods of instruction. Bean (2004) asserted that teachers were introduced to more information about the new program or activities that happened to be more valuable to teaching strategies. Other research revealed the improvement of effective workshops that provide opportunities for teacher training and follow-up for participants (American Educational Research Association (AERA), 2005; Joyce \& Showers, 2002).

\section{Need for Professional Development}

Through the process of learning to teach, Kelleher (2003) found that "with the increasing expectations for students manifested through statewide standardized text in nearly every state and the development of curriculum frameworks throughout the country, a heightened interest in both spending for professional development and the effect of adult learning on student learning has emerged” (p. 1). Therefore, Kelleher (2003) recommends that schools need to develop plans that address specific learning goals and needs of teachers. The report for the National Commission on Teaching and American’s Future (1996) also recommends high quality professional development, rewards for teachers who improve their practice, planning time for consulting or learning new teaching strategies and methods, and mentoring programs for new teachers to improve teacher quality. IRA (2009) and Joyce and Showers (1995) call for creating change in schools in the form of professional development that is far more powerful and pervasive than the one that exists. Therefore, in many studies, effective professional development is identified as one way to engage teachers in learning about instruction through 
modeling, coaching, mentoring, supporting teachers, and facilitating study groups (Moxley \& Taylor, 2006; Doles \& Donaldson, 2006; IRA, 2004/6; Blamey et al., 2008). To further help prospective teachers learn from professional development, Feiman-Nemser (2001) listed five critical elements of all professional development

- Focus on the subject matter being taught;

- $\quad$ Provide learning opportunities;

- Support the real work experiences of the teachers;

- Provide enough time for extended opportunities for teachers to learn and observe and analyze students’ data/ understanding of each subject; and

- Provide ongoing evaluation to expand responsibilities and develop leadership skills.

Feiman-Nemser also stated that effective professional development "must use the combination of reflective logs, dialogue journals, weekly cohort-based seminars, and individual conferences” (p. 1024). In this case, Feiman-Nemser (2001) underscored the importance of matching of appropriate professional development provisions with particular, individual, contextualized professional needs.

\section{Benefits of Newer Models for Professional Development}

Garet, Porter, Desimone, Birman, and Yoon (2001) suggest several ways for improving professional development, including sustained and intensive professional development focusing on an academic subject, giving teachers the opportunity to practice their learning within their own classrooms. Desimone, Porter, Garet, Yoon, and Birman (2002) designed “a series of studies that allowed them to examine the relationships between alternative features of 
professional development and change in teaching practice in a cross-sectional, national probability sample of teachers and a smaller, longitudinal sample of teachers” (p. 3). They hypothesized that some of the key structural features improved teaching practice: reform work type, such as a study group, mentor, and the degree to which there is an emphasis on the collective participation of groups, such as grade level groups, participants from the same school or department. The results indicated that active learning, coherence, and content-focused opportunities positively increase the effect of professional development on teachers' instruction. In addition, it was also found that teachers' involvement in different professional development models could change teachers' attitudes of practices and could even improve students' achievement.

In the Taylor, Pearson, and Rodriguez (2005) study of professional development in schools implementing a school change framework, they found that in schools that have high implementation, there are greater effects when the results are examined after a period of two years. The study by Hill (2009) reported that less than $25 \%$ of teachers indicate that the professional development activities in which they participated during the past three years had impacted their teaching. In the study of Borko, Davinroy, Bliem, and Cumbo (2000) for exploring and supporting teacher change, the authors reported that teachers’ professional development must vary and be flexible to accommodate their characteristics of specific people and situations. They studied professional development that focused on working collaboratively with colleagues at one's school site. The researchers explained that the teams had common goals, shared materials, and the time to support each other on an on-going basis, efforts that are often fostered through common planning periods. Workshop experiences also supported these teachers' learning by providing opportunities for discussion and thoughtful reflection including 
critical conversations about their teaching. The authors found that teaching resources are central to reform efforts and that teachers must have convenient access to them (teaching resources) to embrace the reform, but the resources alone were not enough.

Teachers need to be able to use the resources as a part of their own professional learning before they use the materials with their students. The authors also found that time was a key factor and that teachers may require more years of experimentation before they can integrate new ideas into their teaching. Furthermore, teachers need time to interact with other teachers who are trying to use the same teaching strategies. Authors Borko, Davinroy, Bliem, and Cumbo (2000) further suggest that teacher change begins with the teacher's beliefs, and practices. During the process of change, teachers' beliefs must become the objects of reflection and scrutiny. They conclude that there is no single best way to facilitate teacher change. The successful professional development programs must provide multiple paths and multiple resources that accommodate the needs of all students. Guskey identified observation, assessment, training, and involvement in development process, study groups, mentoring, individual guided activities, and action research as the most essential parts of effective professional development. The result indicated that professional development practices and modes of delivery seem to be of particular value to midcareer teachers. In addition, the practices also recognize that as professionals learn, their knowledge bases become broader and also more specialized and that their capacity to increase and extend their knowledge and skills also grows.

Wold (2003) conducted a two-year study that examined how teachers learned to act on and move toward more advanced literacy teaching by examining the efforts of three teachers to implement guided reading and interactive writing. On-site literacy coaches selected teachers who shifted most in their thinking and deepened literacy practices during an on-going literacy project. 
The results of the study reveal that "learning to act on reflection" is more effective when teachers have a clear sense of "which knowledges to teach when" (p. 52). According to Katz, Sutherland, and Earl (2005), professional learning consists of meaning-making, and this process can be inherently motivating if learning strategies are utilized that encourage problem-solving, inquiry into practice, and collaborative professional support throughout the professional development learning processes (Guskey, 1995; Sheerer, 2000).

The professional development program that build knowledge and success of one school at a time, was opposed (Lipson, Mosenthal, Mekkelsen, \& Russ, 2004) because it lacks the ongoing support for applying strategies and methods teachers learned or selected in order to practice comfortably. Wold reports that changes in teaching practices happen when teachers become more effective and when "their behavior is more strategic when teachers learn to integrate decision-making procedures with knowledge-based actions to advance learners’ literacy independence” (p. 52). Wold finds that coaching is needed for teachers to support strategic decision-making, indicating long-term professional development seemed necessary for developing deliberate literacy instruction. The literature revealed that effective professional development programs are and need to be attentive to broader change processes (FeimanNemser, 2001; Fullan, 2005). Key understanding of the change process (e.g. change in an educational setting involves many people working towards a common goal; change is a process that involves different stages; it is not a one shot event; change requires both pressure and support) needs to be addressed.

In conclusion, professional development needs to be, first and foremost, attentive and responsive to student learning and performance. It needs to attend to authentic themes and issues on the daily activities of teachers that relate to students learning, and it needs to be respectful of 
those theoretical and practical knowledge bases that inform the act of teaching. Therefore, involvement of experienced teachers in study groups, coming together to discuss ideas and issues related to aspects of classroom practice and student learning are viewed as more essential. Feiman-Nemser (2001) described “Descriptive Review” when teams of teachers collaboratively discuss and problem-solve the instructional and program needs of individual learners and participate in study groups and shared classroom observation as collaborative strategies that are highly effective for experienced teachers. In this case, prospective teachers are also an essential element of effective process and instruction, but for them to be flexible and achieve good products about relevant reading instruction, they need support and guidance from coaching.

\section{Coaching}

Several schools and districts are currently using coaching as a primary part of their professional development program (Foltos, 2007; Sailors \& Price, 2010; Bean, 2009). The word coaching, however, is an umbrella term that refers to several kinds of programs with different goals. For example, change coaching emphasizes whole school organizational improvement, peer coaching emphasizes two or more colleagues working together as a team, and collegial coaching emphasizes increase of professional empowerment (Showers \& Joyce, 1996; Neufeld \& Roper, 2003).

In addition, coaching supports teachers with the implementation of the strategies or approaches that may have been introduced or chosen to match the teaching style (Bean, 2009). According to Cassidy and Cassidy (2009/2010), coaching is not new, and it is the process that

will always be in the knowledge of those who lead the field. Sailors and Price (2010) explored the role of coaching as a means of professional development in improving comprehension instruction in elementary and middle school classrooms. The results indicated that coaching is a 
worthwhile tool for the professional development of classroom teachers. Therefore, coaching has become increasingly important as a means to provide professional development for teachers within their school contexts. It is also used to indicate a positive change in individuals and to encourage the transfer of knowledge from coach to teacher. Coaching has also been seen as an approach to develop quality leadership in schools, and its goal is to "support teachers in achieving their own goals and facilitate teacher learning” (Bean, 2009, p. 113). Moxley and Taylor (2006) identified follow-up contact with the teachers as one major benefit coaching brings to professional development. Vogt and Shearer (2007) viewed coaching as an approach that uses a cycle of instruction that allows the coach to provide model the lessons, observe the teacher implementing new instructional strategies, and offer feedback.

In "Professional Learning in the Learning Professional: A State Report in Teacher Development in the United States and Abroad,” Wei, Darling-Hammond, Andree, Richardson, and Orphans (2009) study the effectiveness of teachers and their impact on student achievement. They find that coaching works best in getting teachers to implement new practices in the classroom because literacy coaches provide ongoing assistance to teachers as they attempt new teaching strategies. Joyce and Showers (1996) found that teachers in coaching relationships practice new skills more frequently, apply them more appropriately in their classrooms, demonstrate clearer understanding of the purposes and uses of new skills, and show greater maintenance and improvement in their use of new skills over time compared with teachers not in coaching relationships. 


\section{Needs for Coaching}

Several researchers provided definitions of coaching that include both school-wide planning and mentoring responsibilities (Borko \& Putnam, 1998; Knight, 2004). The coaching process, defined as using the dual-purpose of coaching, involves the literacy coach addressing professional development of teachers as a whole-school literacy advocate and teacher mentor to improve literacy instruction within a classroom setting (Walpole \& McKenna, 2004). Bean (2004) defined a coach differently as "sometimes used to refer to a teacher who works with children to help them become proficient readers; and sometimes it is used to distinguish an expert reading teacher whose job, along with the tasks and roles of working with students, is also responsible for providing support and guidance to teachers so that the classroom instruction for student is effective” (p. 97). In addition, Moxley and Taylor (2006) describe coaching as “a service that enhances curriculum, instruction, assessment, professional development, resources, intervention, and community engagement to improve reading, writing, and content learning” (p. 9). In general, coaching is described as the procedure of assisting others to increase their working skills and gain confidence and motivation in their teaching process. According to Lyons and Pinnell (2001), “coaching provides the support teachers need to engage in classroom inquiry” (p. 154). 


\section{Models of Coaching}

Rita Bean (2004) stated that the role of the coach can vary because of the "readiness of the teachers” (p. 110). She explained five models of coaching that can help those interested in coaching, administrators, and those who prepare to be reading specialists:

(a) Peer coaching model

(b) Resource model

(c) Teacher as a learner model

(d) Prescriptive model

(e) Goal oriented model, and

(f) Context of school model

Peer coaching approach is explained as colleagues working with each other to provide feedback and support. The model is viewed as the most essential approach that highlights the equal positions of both coach and teacher as they work together to promote the quality of teaching and learning (Joyce \& Showers, 2002).

The primary goal of the resource model is to allow the literacy coach or reading specialist to work with individual teachers in various ways such as learning to differentiate instruction and providing assistance in the ways teachers could be successful in their classrooms.

According to Bean (2009), the primary goal of the teacher as learner model is for the coach to support teachers in "achieving their own goals and to facilitate teacher learning” (p. 113). This type of coaching focuses on the importance of listening to teachers; understanding their needs, interests, and problems; and treating them equally to improve their confidence or self-esteem in teaching. 
The implementation model is divided into two different parts: the prescriptive model and the goal oriented model. In the prescriptive model, there is no choice. Teachers implement everything in the curriculum designed for them (e.g. approaches, materials, strategies). In the goal oriented model, teachers are provided with more opportunities for choice from the specific goals that are identified by the school. In this model, the coach decides whom to work with during the process.

In the context of school model, the coaching focus is on the relationship of the culture, teachers, and students' learning. The main primary roles and responsibilities of coaching are as follows:

- Assist teachers with embedded professional development

- Develop or share resources with teachers

- Develop curriculum or prepare materials

- Lead in study groups to discuss specific materials or topics read by the groups

- Lead workshops, observe and provide feedback, co-teach, and model lessons (Bean, 2004, p. 121).

Rodgers and Rodgers (2007), Moran (2007), and Burkins (2007) consider coaching an essential component of professional development to help improve teachers' instruction although each one describes it differently. Rodgers and Rodgers claim that the job of the coaching is to work with teachers on the edge of their learning. The authors provide many practical examples of how coaching can improve instructional practice. When working with novice teachers, the coach might be working strictly on basic teaching techniques. When working with more experienced teachers, the coach might be working at the edge of expertise as well as that of the teacher. 
Together they solve problems. Rodgers and Rodgers find that several types of coaching scaffold reflection and foster change in teachers' practices.

One type is side by side coaching where a coach sits beside the teacher during instruction allowing for quiet conversation and collaboration. The coach observes a lesson in which the teacher might pause ever so briefly, and at that exact moment, the coach provides explicit directions, limited to only two or three words. Visiting is another type of coaching that scaffolds reflection. These visits may take several forms, i.e., cluster visits, school visits, rolling cluster visits, colleague visits, and targeted coaching. A coach may embrace any one or a combination of these depending on the needs and the circumstances of the students. A cluster visit or cluster coaching promotes reflection on action because it takes place after the teaching event, which also makes it easier to document. During a cluster visit, the coach is joined by several teachers who are also being coached. The focus is on the teaching and learning of all the teachers, rather than focusing on a single teacher. This is accomplished by momentarily suspending the teaching, allowing time for the group to reflect. A school visit is specifically targeted for the purpose of conducting observations and reflection focused on specific tasks. A rolling cluster visit builds on a cluster visit but takes the coaching into an individual teacher's classroom. Colleague visits provide opportunities for teachers to visit in another teacher's classroom and undertake reflective practice by questioning assumptions, choosing courses of action, and implementing possible plans. Focused coaching allows the coach to observe a teacher present a lesson. Prior to the lesson, the teacher establishes a goal and discusses it with the coach. The teacher implements the lesson and the coach observes. After teaching the lesson, the teacher reflects on the lesson and discusses it with the coach (Rodgers \& Rodgers, 2007). 


\section{Benefits of Coaching}

Therefore, coaching can be an essential element of professional development as coaches support teachers in developing content knowledge while simultaneously improving their teaching (IRA, 2004/2006; Blemey, Mayer, \& Walpole, 2008). Forgarty and Pete (2007) found that the most powerful, job-embedded, authentic application of professional development is coaching because it improves instruction and is recognized as an effective professional development model (International Reading Association [IRA], 2006). In addition, coaching can provide the continuous support, assistance, follow-up, and feedback needed by teachers as they attempt to either master new or change instructional practices (Bean, 2009; Joyce \& Showers, 1996; IRA, 2004; Deussen et al., 2007; Dole \& Donaldson, 2006; Moxley \& Taylor, 2006; Vogt \& Shearer, 2007; Sturtevant, 2003). Wold (2003) finds that coaching is needed for the teachers to support their increasingly strategic decision-making, indicating long-term professional development deemed necessary for developing deliberate literacy instruction. Sailors and Price (2010) found that coaching might be a model of professional development that could support teachers in all the grades to improve reading.

Kohler, Ezell, and Paluselli (1999) further report numerous positive outcomes of coaching: teachers' ability to plan and organize, to provide instruction for students with disabilities, to use classroom behavior management strategies, and to address instructional objectives. These authors also report that teachers are more likely to implement changes in instruction while being coached than while working independently, and that the changes made during the coaching phase are sustained after coaching. In the study of Van Keer and Verhaeghe (2005) that compared a year-round intensive coaching model with a more restrictive model for 
second- and -fifth grade teachers, the authors find that both treatments are equally effective in changing students’ reading comprehension, strategy use, fluency, and self-efficacy.

In a CIERA study, one important finding is that "coaching positively" accounts for 11 percent of the teacher variance (p. 55). They also found that for every $10 \%$ increase in the coding of coaching within a classroom, students' mean writing scores (based on a 4-point rubric) increase by 0.08 . In their finding, the authors clearly list the classroom level and school level variables that accounted for growing such as coaching, high level of questioning, and students' writing growth. Another study by Blasé and Blasé (1999) discussed six essential parts of staff development that include the study of teaching and learning, collaboration, coaching, inquiry, resources to support improvement, and applying principles of adult learning. From their findings, staff development created certain conditions to assist teachers in learning teaching strategies and they use support to develop strategies such as peer coaching. A study of 12 teachers and 8 coaches by Gutierrez, Crosland, and Berlin (2001) found that teachers in coaching relationships do not change their classroom activities in functional ways, and also a study by Veenman, Denessen, Gerrits, and Kenter (2001) found that the relationships of teachers who have been coached relate as no more effective than their non-coached peers when observed by experienced teachers.

\section{Challenges of Coaching}

Gersten and Morvant (2006) conducted studies to evaluate the reasons for the lack of implementation of research-based instructional practices. These researchers find the following barriers to curricular improvement: lack of time, large class sizes, teachers' and administrators' long-held instructional preferences, and high stakes assessment (p. 62). 
In the countries as a whole, coaching is clearly needed in teacher learning because it is an approach in which teachers are helped to improve their quality of teaching and assist students. Therefore, successful coaching need not only favorable background conditions to support coaching but also a coach who has the skills, abilities, and understanding of the model of coaching that has been implemented. In this case, a literacy coach is deemed the right person to guide teachers with reading instruction while they are learning to teach.

\section{Literacy Coach}

According to the research, literacy coaching in the area of reading is not new to the educational landscape (Bean, 2004). For example, Vogt and Showers (2007) find concern about students not becoming proficient readers dating back to the late 1960s. These concerns caused an infusion of funding into public schools, resulting in a small number of classroom teachers being assigned the responsibility for assisting students to become more proficient in reading. Some of these teachers were expected to work at both the school and district level with a wide variety of titles such as reading specialist or reading resource teacher. Later, reading specialists became common in most states until the 1990s when budget cuts began to eliminate these positions (Vogt \& Showers, 2007). The reading specialists range from assistant, to integrated collaborator with the emphasis on high quality first instruction in the 2002 No Child Left Behind legislation. Reading specialists were now counted on to guide development of formal assessment instruments as the reading coaches. After that, literacy coaches continued expanding in the educational landscape with the goal of closing the achievement gap and of meeting the provisions of the No Child Left Behind (NCLB) Act 2001. The Act requires teachers to receive substantial professional development and literacy coaches to assist in the schools (Taylor, Moxley, Chanter, \& Boulware, 2007; Poglinco \& Bach, 2004). 
The CIERA study that published by National Institute of Child Health and Human Development (2000) and references the Report of the National Reading Panel: Teaching Children to Read (2000). The NRPT recommends that specific areas of reading instruction need to be included in every curriculum to assist children in learning to read. The report recommends that children receive instruction in phonics, phonemic awareness, vocabulary, comprehension, and fluency. However, the authors suggest that “to significantly improve students' reading achievement, teachers need to consider the larger possibility of research summarizing the pedagogical practice of effective teachers of reading...the how of reading instruction” (p. 44). The authors express concern that teachers of reading instruction need to focus only on those five areas, excluding other important areas, especially the reading of authentic text.

They also find that the reform model accounts for between-school variance in reading growth when examined for one year. Over a two-year period, comprehension scores account for substantial differences in between-school variance in comprehension. Another finding is that schools with more growth have a teacher leader who is respected by colleagues and who helps the other teachers to address important topics during weekly staff meetings. The teacher leader was effective even when the school administration is not participating in staff development but supports the teacher leader's efforts to provide staff development for teachers. The Center for Improvement of Early Reading Achievement Report (CIERA): An Evidence-Based Approach to Professional Development and School Reading Improvement (Taylor, Pearson, Peterson, \& Rodriguez, 2005), listed five main elements related to high-performing, high poverty schools: (i) strong building leadership, (ii) strong staff collaboration, (iii) ongoing professional development, (iv) sharing of student assessment data, and (v) parental involvement (p.44). The authors further 
explain that to improve comprehension scores, fluency scores, and writing, strong leadership and staff collaboration are needed for relevant instruction.

\section{Defining Literacy Coaching}

Literacy coaching currently is “one of the responses to the need for improving reading achievement and reducing the achievement gap that exists in the United States” (Belcastro, 2009, p. 10). Puig and Foelich (2007) define a literacy coach as someone who co-learns and assists in shifting classroom teachers to better understanding critical pedagogy and the need for change based on evidence. Poglinco, Bach, Hovde, Rosenblum, Saunders, and Supovitz (2003) explained that the rationale behind having a literacy coach is rooted in research on creating an effective professional development environment, that provides ongoing support to teachers and creates a learning community that includes structures for focusing on instruction and curriculum. These authors explained that changing teachers' practices is grounded in the coaches' pedagogical knowledge of literacy processing and founded on collegial trust (Poglinco et al., 2003). Sailors and Price also defined a literacy coach as someone who improves reading achievement of students and improves the ability of teachers to effectively teach their students.

With literacy coaching focuses is on classroom teachers and supporting their daily instruction. The literacy coach has to complete several years of high quality teaching (Deussen \& Buly, 2007; IRA, 2004; Bean \& Swan Degan, 2012; Lynch \& Ferguson, 2010); has to have an extensive background in reading instruction, either through graduate level coursework or high quality professional development and has to have experience modeling lessons in a classroom setting, observing teachers, and providing feedback to teachers. Literacy coaches are also given roles as resource teachers, staff developers, reading teachers, or evaluators (IRA, 2004; Sturtevant, 2003; Bean, 2004/2009; McEachin, Dorman, Reed, Gillmore, \& Bray, 2006). A 
literacy coach has to have experience as a presenter and facilitator of adult learning and has to have an understanding of adult learning (Blamey et al., 2008; Forbes \& Johnson, 2008; Tallerico, 2005; Butler, Forbes, \& Johnson, 2008). H/she must be seen as professional with her/his own set of professional development needs (Sturtevant, 2003).

Moran (2007) offers three essential goals of coaching: (a) to establish a school culture that recognizes collaboration as an asset, (b) to develop individual and group capacity to engage in problem solving and self-reflection, and (c) to provide a continuum of professional learning opportunities to support adults in their acquisition and use of specific knowledge and instructional strategies. Moran suggests that teachers approach teaching as a series of opportunities to respond to rather than react to. Because teaching is such important, complex work, it should not be done in isolation, but rather with colleagues.

\section{Roles and Responsibilities of the Literacy Coach}

Dole and Donaldson (2006) stated that

Although reading coaches may wear many hats, their primary and most valuable activity is working directly with teachers in their classrooms. They model how to teach reading and writing lessons for teachers. They observe teachers teaching reading and writing activities and provide feedback on their lessons. They assist and support teachers as they learn new reading instruction skills and techniques. They also support and guide classroom teachers while acting as mentors and assistants (p. 486).

Bean and Swan Degan (2012) report similar roles of literacy coaches as Dole and Donaldson. Because a teacher's ultimate goal is to increase student learning and achievement, one of the main responsibilities of a coach is to assist with that goal; therefore, the focus of literacy coaches needs to be on the support of teachers (Toll, 2008), specifically in changing their teaching practices (Rodgers \& Rodgers, 2007; Marsh, McCombs, \& Martorell, 2010). To further describe the role and responsibility of literacy coaches, IRA (2004) states that a literacy coach needs 
- to serve as a resource in the area of reading for teachers, administrators, and community;

- to work cooperatively and collaboratively with other professionals in planning programs to meet the needs of diverse populations of learners;

- to provide professional development opportunities at the local and state levels

- to provide leadership in student advocacy; and

- to provide specialized reading and writing instruction, and assessment in cooperation with other professionals (special educators, speech and language teachers, school psychologists) and diagnoses to students at one or more of the following levels: early childhood, elementary, middle, secondary, or adult (p. 7).

Rodgers and Rodgers (2007) insist that although literacy coaching positions may be complex, coaches need to differentiate their work depending on the culture of the schools, the needs of the individual teachers, and the nature of the particular coaching situations "to create a coaching plan that is robust but makes sense” (p. 134). Burkins (2007) also explained the role of literacy coaches as complex, with the coach wearing many professional "hats," but Burkins explained the many "hats" by defining the coach as "an educator with specific expertise and extensive experience in literacy instruction by providing individual coaching, attending team meeting, formal professional learning, modeling lessons, visiting teachers in their classrooms, and providing various other contexts, works with and for teachers to lead, assist, and honor them as they solidify and expand their skills in and understandings of literacy instruction” (p. 29). Literacy coaches have provided leadership for a school’s literacy program and have been identified as key players in making effective change in schools (Hasbrouck \& Denton, 25; Moxley \& Taylor, 2006; Sturtevant, 2003). 
Lyons and Pinnel (2001) described a literacy coach as a professional developer who will "introduce, describe, and demonstrate topics in class sessions and then be able to provide direct assistance and coaching in classrooms” (p. 52). Poglinco, Bach, Hovde, Resenblum, Saunders, and Supovitz (2003) stated that literacy coaches need to be excellent reading teachers, teaching at their level; have in-depth knowledge of processes, assessment, and reading instruction; and have experience or preparation that enables than to model, observe, and provide feedback about instruction. Literacy coaches also facilitate and encourage collaboration between teachers and administrators (Blamey et al., 2008; Mraz, Algozzine, \& Watson, 2008; Bean, 2009).

Overcoming teacher resistance is one of the most difficult aspects of the literacy coaches' duties because Zimmerman's (2006) research found that some teachers are resistant to change due to fear, failure to recognize the need for change, and perceived threats to power. To overcome teachers' resistance to change, it is important that literacy coaches spend a great amount of their time working to build trusting relationships (Deussen et al., 2007).

Some studies document the effectiveness of coaching specifically for improving the practice of teachers. For example, the use of literacy coaches as a form of professional development with classroom teachers has improved teachers' interactions (Domitrovich, Gest, Gil, Bierman, Welsh, \& Jones, 2009; Pianta, Mashburn, Downer, Hamre, \& Justice, 2008) as well as the quality of instruction teachers offer (Neuman \& Cunningham, 2009) to their students. The use of literacy coaches has been shown to increase the amount of time dedicated to literacy instruction, including time devoted to key components of literacy instruction, instruction with small groups, and time spent using a systematic, comprehensive program (Carlisle, Cortina, \& Katz, 2011). In addition, the use of literacy coaches also improves the quality of the learning 
environment in classrooms (Todd \& Cohen, 2008; Powell, Diamond, Burchinal, \& Koehler, 2010), and the use of reading strategies created for their students (Sailors \& Price, 2010).

Other studies document the change in teachers' beliefs as the result of the work of literacy coaches. For example, Frey and Keely (2002) conducted a study over two years with teachers who worked with a coach. The coach describes teachers' practices aligned with their beliefs. In another study by Pianta et al., (2008), a group of teachers were provided with webbased professional development plus coaching by consultants. Authors found that teachers who had longer lessons, and higher quality teacher-child interactions, prevent misbehaviors that used more stimulating language instruction than teachers who receive only the web-based professional development.

In short, teachers in an intervention group indicated greater growth in "reading and responding to students' cues, using a variety of formats to actively engage children in instruction, and intentionally stimulating language development” (Pianta et al., p. 443) than teachers in the web-based group. Some teachers appreciated "direct and explicit messages from the coach and report that they find it motivating to interact with coaching consultants” (Shulman, 2004, p. 396). Deussen, Coskie, Robinson, and Autio (2007) report that sometimes directive coaching created conflict with teachers who resisted being told what to do. These teachers who resisted, reported they would rather have conversations with their peers than with site administrators, district consultants, or university faculty (Lapp, Fisher, \& Frey, 2003). Biancarosa, Bryk, and Dexter (2008) explored the connections between professional development and changes in teacher instruction. Their findings indicate collaboration between literacy substantial improvement in literacy teaching that correlate with the amount of professional development and one-on-one coaching the teachers receive. 


\section{Need for Literacy Coaching}

Ball and Cohen (1999) answered this question: What would teachers need to know in order to teach in the way researchers and educators imagine they should? First, teachers would need to know the content of the subject matter they teach in order to understand the connections and greater meanings of the content. To support children as they construct conceptual understandings, teachers must themselves have a great depth of knowledge and make connections across fields. Second, teachers need to know about the children they teach, their strengths well as what they have yet to learn. Third, teachers need to understand children's cultural and gender differences, and how to meet the needs of all students. It is important for teachers of English language learners to understand the cultural differences represented in classrooms. Teachers also need to develop and expand their ideas about how children learn. Additionally, teachers need to advance their pedagogical knowledge and develop a repertoire of ways to effectively engage and respond to their students. Ball and Cohen further explain that an inquiry stance means that teachers "need to learn how to investigate what students are doing and thinking, and how instruction has been understood as classes unfold” (p.11). The authors suggest focusing opportunities for learning on teachers' practices through analyzing student work samples, curriculum materials, and videotaped lessons.

Walls, Nardi, von Minden, and Hoffman (2002) conducted a study with 90 teacher participants to find characteristics of effective teachers. The study listed the following results: "the most effective teachers motivate their students and had little difficulty with classroom management. Their care about student accomplishment and advocacy for student success set the tone for fair rules and grading. Such teachers are frequently depicted as requiring and maintaining high standards of conduct and academic work” (p. 42). 


\section{Benefits of the Literacy Coaching}

Hough, Bryk, Pinnell, Kerbow, Fountas, and Scharer (2008) examined whether a variance in teacher practice is associated with the amount of time the literacy coach provides to teachers. These researchers report that the amount of coaching time spent with a teacher appears to be related to the increase in teachers' use of the Literacy Collaboration model. In the Hough study, literacy coaches received training in the model for a year while they continued to model these components (read aloud, shared reading, guided reading, and writing) for classroom teachers to integrate into their practice. The researchers found that a literacy coach with more professional development experience resulted in a higher incidence of teachers following the parts of the Literacy Collaboration model in their classrooms. The use of a literacy coach indicates positive results in how frequently and successfully teachers implement their effective practices. The researchers also find that the teachers' level of implementation is greater when the literacy coach has previous experience in staff development. Hough et al., (2008) discovered that a school with a highly experienced literacy coach is more likely to see teachers increase the use of literacy strategies in their classrooms.

Walsh-Symonds (2002) examined coaches as they assisted teachers individually by observing and demonstrating effective strategies in classrooms, assisting teachers in using research, and offering staff development. The main benefits of this kind of coaching indicate an increase in the amount and quality of the use of new instructional strategies and teachers' improved reception to change. The author also reported that the district need to organize, fund, and support literacy coaches in schools, as well as to develop a clear description of collaborating with administrators to provide professional development for coaches. 
Another study was conducted by Bean, Swan, and Morris (2003) regarding leaders (Literacy Educators Assessing and Developing Reading Success of K-3). The professional development was done practically with teachers in schools with low student achievement and high poverty. The focus of the study was enhanced student performance. The results indicate that students make significant progress in each of the reading activities performed. Teachers also indicated a significant growth on the instrument they used with the support of the coach. Teachers' satisfaction was indicated as high through the measurement of various questionnaires and group discussion meetings. Teachers also report that they value the opportunity "to talk with others who taught at the same grade level or in the other schools or districts” (Bean, 2009, p. 97).

In case studies of effective coaches, Steckel (2009) finds that coaches need to show teachers evidence that proposed changes will benefit students more than their current practices before they implement the new practices. This should happen before the coaching begins. One of the most effective coaches in this study first modeled the strategies with students in the teacher's classroom. During the modeling, teachers had opportunities to observe the strategies personally. After the lesson, the coach had the opportunity to explain the rationale of the lesson, activities, and strategies.

A study conducted by the RAND Corporation by Marsh, McCombs, Lockwood, Martoreel, Gershwin, Naftel, Shea, Barney, and Crego (2008) analyzed district reform efforts. One part of this study focused on supporting the professional learning of teachers through the use of a school-based coach. The aim was to evaluate the impact of coaches on student achievement and design support networks for the coaches in order to support their learning and effectiveness. Results indicated that having literacy coaches in schools was related to a small improvement in reading, with the number of years a coach was employed in a school linked to higher reading 
scores. Some of the recommendations based on this study included the following: coaches need to review assessment data with teachers, coaches need to assist school administrators in determining how to select high quality coaches, and districts and schools need to continue to provide professional development for coaches. Researchers also recommended that administrators need to learn how to identify high quality coaching candidates and offer incentives to support and retain highly qualified coaches.

\section{Challenges of the Literacy Coaches}

Literacy coaches took on even more responsibilities that are difficult to categorize, such as writing grants and providing technology support. Other duties might be classified as schoolwide efforts to motivate students in areas of reading and comprehension. In addition to their responsibilities, L’Allier and Ellish-Piper (2009) indicated additional examples that might be challenges to the literacy coaches' activities, for example, assigned time for coaching in the school. The spirit of trust and communication among teachers and literacy coaches was found more essential in the process of learning to teach reading (Bean \& Swan Degan, 2012). Furthermore, a small number of studies show that literacy coaches have little or no effect on improving teachers’ practices or improving student achievement.

In addition, research further indicated that there is a little of proof about how a literacy coach supports teachers to improve reading instruction in the classrooms (Dole \& Donaldson, 2006; IRA, 2006; Neufeld \& Roper, 2003). Neufeld and Roper (2003) also contend that because some veteran teachers who do not utilize new approaches may be regarded as experts by their colleagues because of increasing student achievement scores, then implementing reform continues to be a challenge for coaches. A study by Rainville and Jones (2008) describe the difficulty in helping a teacher understand that a running record can provide information for 
designing more effective reading instruction. The classroom teacher saw the running records as something to finish and submit to the administration quickly instead of seeing the benefits of the running records for her teaching and student learning. In another case study, Otaiba, Hosp, Smartt, and Dole (2008) examined the challenges of literacy coaches. The coach in this study found it difficult to convince teachers to implement phonological awareness and phonics strategies because these strategies differed both from the meaning-based core reading program that the district uses and from the teachers' beliefs in a whole language approach to reading and writing instruction.

\section{Summary}

Chapter two presented the study within earlier research with a review of the literature on learning to teach that attempts to untangle the roles pre-teaching experiences play in the process of learning to teach reading. The review of research is organized to mirror the continuum of learning to teach. I began by examining the teacher learning framework from preservice to post induction, moving to the teacher learning and professional development and to the main part of this study called literacy coaching. Drawing on situated theories of learning, I chose to examine what research has to say about the role that these contexts play in teachers learning to teach. Although learning to teach reading is not a direct transition, situating the review in this way demonstrated that knowledge gets constructed and reconstructed over time depending upon the professional development, coaching as a whole, and responsibilities of the literacy coach (which can be social context, interactions, and experiences) that one encounters during the process of becoming a teacher. It is clear that teacher learning and the process of learning to teach matters a lot because a growing body of research reveals the importance of the literacy coach and teacher education programs more broadly (Bean, 2004, 2009; Cochran-Smith, 2001; Feiman-Nemser, 
2001; Zeichner, 2000). Coaching is also indicated as an essential approach to provide continuing professional development (Rodgers \& Rodgers, 2007; Moran, 2007) when teachers are supported in their acquisition and instructional strategies in the classroom (Moran, 2007) through the help of a highly experienced coach.

With this study, I strove to understand this gap by examining three strands related to coaching and teacher learning. The first strand was focused on how literacy coaches support (or does not support) classroom teachers in learning to teach reading in their classrooms: How does elementary literacy coach support (or does not support) classroom teachers as they learn to teach reading in ways that meet the needs of their students? The second strand of the study was focused on the way the approaches used by a literacy coach influences teachers' reading instruction: How does the coaching influence the ways in which a classroom teacher plans for and carries out reading instruction? The final strand was focused on the way coaching and learning to teach can be influenced by the environment: How does the context(s) in which the literacy coach and teachers are situated influence the nature of the coaching and the ways in which classrooms teachers learn to teach reading? 


\section{Chapter Three}

\section{Research Methods}

Children are struggling to read at their proficiency levels in classrooms, and literacy coaches have been employed to support teachers as they learn how to meet the needs of all learners, but little is known about what actually happens during the one-on-one coaching between literacy coaches and the teachers they are coaching. In this study, I examined how a literacy coach and the classroom teachers who were coached experienced the coaching sessions designed to improve the practices of classroom instruction.

The purpose of this qualitative study was threefold. First, I examined how an elementary literacy coach supported (or does not support) classroom teachers learn to teach reading in ways that meet the needs of their students. Second, I determined how the coaching influenced the ways in which a classroom teacher planned for and enacted reading instruction. Finally, I understood how the context(s) in which the elementary literacy coach and teachers were situated influence the nature of the coaching and how the classroom teachers learned to teach reading.

\section{Rationale for Qualitative Research}

A qualitative research approach was chosen for this investigation. I felt it was best suited for the goals of my study because this approach helped researchers to understand people’s knowledge and experiences in their world. Creswell (2007) noted that qualitative research is appropriate when a problem needs to be explored, a complex understanding of an issue is

needed, people need to be empowered to share their stories, and/or interactions need to be captured. Qualitative researchers “attempt to capture data on the perceptions of local actors from the inside” (Miles \& Huberman, 1994, pp. 6-7), examine how people make sense of their 
work, and understand their experiences in a particular context (Merriam, 1998; Creswell, 1998; Patton, 1994).

Qualitative researchers "study things in their natural settings, attempting to make sense of or interpret, phenomenon in terms of the meanings people bring to them” (Denzin \& Lincoln, 1994, p. 2). These scholars also "stress the socially construct nature of reality, the intimate relationship between the researcher and what is studied, and the situational constrains that shape inquiry...[and] seek answers to questions that stress how social experience is created and given meaning” (Denzin \& Lincoln, 2002, p. 8). Therefore, the qualitative research approach of this study provided me with the theoretical framework and practical tools to understand how literacy coaches provided support to classroom teachers and how these teachers thought about and were influenced by their experiences learning to teach reading. It was my intent to gather data to illuminate the perspectives of the participants and, with their assistance, construct an understanding of the professional experiences of literacy coaches and classroom teachers during coaching. The questions I explored were the following:

1. How might an elementary literacy coach support (or does not support) teachers as they learn to teach reading in ways that meet the needs of their students?

2. How does the coaching influence the ways in which a classroom teacher plans for and enacts reading instruction?

3. How does the context(s) in which the literacy coach and teachers are situated influence the nature of the coaching and the ways in which classroom teachers learn to teach reading? 


\section{Theoretical Framework}

Two complementary theories grounded this study: constructivism and social constructivism. They offered a compelling framework for the study of teacher learning and of the support literacy coaches provided teachers while they learn how to teach reading. Constructivism held that people construct their own understandings and knowledge of the world they live in through their personal experiences and interactions (Patton, 2002; Crotty, 1998; Creswell, 2009; Vygotsky 1978). The social constructivist viewed posits that culture has a hold on each individual and influences the ways in which one makes sense of the world (Crotty, 1998). Thus, social interactions and collaboration with others provided opportunities for new understandings to develop. Therefore, according to social constructivism, literacy coaches and teachers who had the opportunity to share their ideas and thoughts on reading issues (Roths, 2009) were able to construct individual understandings of how to teach reading that are influenced by the interactions provided during the coaching sessions.

One of the most essential concepts underlying Vygotsky’s social constructivist theory was "the zone of proximal development” (ZPD). The ZPD maintains that a learner follows the adult's example and gradually developed the ability to do certain tasks without help or assistance. The premise of the idea is the level at which a learner can be successful with appropriate support. Thus, the zone of proximal development is "the distance between the actual developmental level and one’s independent level as determined through problem solving under adult guidance or in collaboration, with more capable peers” (Vygotsky, 1978, p. 86).

One central characteristic of the ZPD related to this study is the role of language and the dialogue a teacher and learner engage in that contributes to the social construction of knowledge. In the zone of proximal development, teachers can learn to teach reading if they are provided the 
space and support they need to develop the skills necessary to complete the task independently. Thus, social constructivists view learning as the ways in which social interactions influence the understandings individuals construct.

Vygotsky also maintained that learners are able to construct understandings of challenging content/phenomena with the support of a more knowledgeable other (MKO). The MKO has a deeper understanding than the learner regarding a particular task. The support that an MKO provides is termed "scaffolding," which is provided to learners as they work in their zones of proximal development. The more knowledgeable other (a coach) adjusts or differentiates the amount of support, time, and guidance provided to the learners (the classroom teachers), so they are able to accomplish the task at hand. Dialogue is an essential tool and provides the medium through which the coach and teachers learn as they discuss and come to understand methods of teaching reading and communicate about children's reading. Rodgers and Rodgers (2007) stated that "an essential feature of effective scaffolding is pitching help at just the right level of sensitivity” (p. 74). Therefore, literacy coaching is not only about the kind of support that is offered, but also about how it is offered.

\section{Methods}

I discussed the process of the Institutional Review Board (IRB), the research context, participants, data sources and collection, data analysis, trustworthiness, and the limitations of the study. Permission to conduct the study was obtained from the school principal (i.e., Appendix: E, literacy coach and from the two teachers IRB approval from mid-Atlantic University was obtained prior to the collection of data (i.e., Appendix: G). I met with the school principal, literacy coach, and two teachers to explain the process of the research, the expectations for the participating, and how the study would contribute to knowledge in the field of literacy coaching. 
Both Patton (2002) and Merriam (1998) stated that protection of the participants is a fundamental priority. All participants were informed of the purpose and goals of the study and the role I would play. A consent form, which provided a detailed explanation of the study, was presented to and signed by each participant before data collection began (i.e., Appendix: F). The participants were informed that each interview would be audio-recorded and that pseudonyms would be used to ensure the confidentiality of participants and contexts in all written documents associated with this study. The participants were also informed that they had the option of leaving the study at any time. Throughout this study, participants had the opportunity to provide feedback about the interviews and my interpretations.

The literacy coach was asked to recruit two teachers, one experienced and one novice. An experienced teacher was one who had attended professional development and interacted regularly with the coach. A novice teacher was one who had participated in professional development with the literacy coach and had been coached two to three times in the classroom. After the coach asked the teachers if they were willing to participate in this study, I met with each nominated classroom teacher to explain the purpose and procedures of the study. They were given two copies of the consent forms. One was signed and returned to me. One was for the teacher to keep. 


\section{The Research Context}

Miles and Huberman (1994) suggested that thick descriptions of phenomena produce rich text and lend themselves to describing and explaining the complexities of real life subjects and situations. Setting a focus and boundaries was essential because there was a limited amount of data collected on any given phenomenon. The boundaries of this study were defined by the following descriptions: the site, the participants, the data source and collection, and data analysis. I have used pseudonyms to protect the anonymity of the sites and the participants and to know how to describe the data of this research.

Brits Elementary School was selected to be the site of this study as it was considered a large public school district in mid-Atlantic state implemented Common Core Curriculum, and provided a long-term professional development program for teachers who were responsible for literacy instruction in their classrooms. Moreover, the county had promoted reading, writing, and math through employing literacy coaches in each elementary school, and all classroom teachers, resource teachers, para-professionals, and administrators had the opportunity to participate in professional development on literacy.

The County School district in which Brits Elementary was located had a total population of approximately 90.8\% White; 3.9\% Black; 2.0\% Hispanic; 2.0\% Asian; 0.1\% Native Hawaiian; and 1.2\% Multi-Racial. The school system employed 734.50 classroom teachers and 153 professional personnel, most of whom were Caucasian. This district had a high population of low socio-economic students: $60 \%$ of them are eligible for free lunch, $28 \%$ are eligible for reduced lunch, and $12 \%$ are ineligible for free/reduced lunch.

Brits Elementary School is resulted from the merger of two schools, Afton Elementary Schools and Zello Elementary School. Neither school met the Annual Yearly Progress score for 
2009-2010. Afton Elementary School students scored 58\%, and Zello Elementary School students scored $49 \%$ in math. Both schools scored $46 \%$ in reading/language arts. When the two schools closed, 62 professional personnel, 60 staff members, 17 service personnel, and 484 students were affected.

In 2011, 87\% of the staff from both schools agreed to consolidate, and Brits Elementary School become the newest school in this district in 2012. Brits Elementary is a green school and uses sustainable practices to save energy, promote good health and safety, and keep cost and waste low. Ultimately, this school was selected because it is dedicated to promoting students' learning and to ongoing professional development in literacy for their teachers and administrators.

Brits Elementary School had a population of approximately 665 students who were 38\%White; 25\% African American/Black; 12\% Hispanic, and 25\% Multi-Racial. The school accommodated students from PreK-5. It also had a high population of low socio-economic students: $45.7 \%$ of them are eligible for free/reduced lunch. Brits Elementary School had 60 professional and 20 in-service staff. The school has 6 classrooms of PreK, 5 classrooms of Kindergarten, 4 classrooms of first grade, 5 classrooms of second grade, 4 classrooms of third grade, 4 classrooms of fourth grade, and 3 classrooms of fifth grade. 


\section{Participants}

I used purposeful sampling to select one literacy coach and two teachers for this study. Purposeful sampling provided the “information-rich cases” (Patton, 2002; Merriam, 1998) I needed to explore my research questions. The literacy coach was selected to participate in this study based on being trained through the Literacy Collaborative that emphasizes ongoing professional development. In addition, the literacy coach was selected, met the criteria of being a coach as described by IRA (2004) or had similar academic education in reading from the institution that

- provides specialized reading and writing instruction assessment in cooperation with other professionals

- serves as a resource in the area of reading for teachers, administrators, and the community

- works cooperatively and collaboratively with other professionals in planning programs to meet the needs of the diverse population of learners

- provides professional development opportunities at local and state levels

- $\quad$ provides leadership in student advocacy

- has previous teaching experience and has a master's degree with concentration in reading education (p. 7).

I was not familiar with the schools in the county, but I wrote an email to the district vicesuperintendent requesting contacts of the literacy coaches in district schools who might participate in the project. In the email, I provided all the details, goals, procedures of the study, and the qualifications and experience required for a participant. But since personal information is confidential, she replied and informed me that she would forward my email to all the literacy 
coaches and provide them with my contact information. Within two weeks, Mary from Brits Elementary School replied and agreed to volunteer in the project.

We began communicating through email. After I got the IRB approval, I met Mary and the school principal to explain the details of the study and to get their signatures. I requested that Mary (literacy coach) recruit two classroom teachers to be interviewed based on her recommendations. The two teachers needed to differ in their years of teaching experience (novice and experienced) and in the grade levels they teach. Both teachers had to participate in school-based professional development sessions focused on literacy. In addition, they had to have different "levels" of expertise related to teaching reading, as assessed by the literacy coach (very skilled and unskilled). They were representative of the population of teachers in this school and across the district. After Mary recruited the two teachers, she informed me, and I met with all of the participants including the literacy coach to explain the details of the study. The two teachers were one male and one female. To complete the discussion and writings of this study, the male teacher was named Bob, and the female teacher was named Nancy.

\section{Mary, Literacy Coach}

Mary has had comprehensive professional development focused on literacy. Because the main role of a literacy coach is to support classroom teachers' literacy instruction, it is important that the coach has comprehensive knowledge of reading processes, achievement, assessment, and instruction (IRA, 2004). Mary’s story provided understanding into one literacy coach’s development and the many ways this knowledge can be increased.

Mary is a white, a mother and happily married. Mary is a well-educated coach who explained that she believed in the type of education provided in the school and wanted all children to benefit from well-structured instruction and teachers who have thorough knowledge 
of teaching reading. Mary is a certified K-8 teacher. She has a Bachelor's degree in elementary education and a Masters in reading. The school in which Mary works has Title 1, and 45.7\% of students are eligible for free breakfast and lunch. Over 25\% of students are Multi Racial and are English language learners (ELL).

\section{Mary's growth as a teacher and literacy coach}

Mary’s husband was in the military, and she has taught in seven different states. She has $20+$ years of teaching experience. She taught kindergarten through $5^{\text {th }}$ grade. She taught at Mayville for five years. Mary valued her two different teaching experiences in Fairfax County as the most essential ones to her life because she received excellent training there. She was proud to explain that she brought those experiences from Fairfax to the county she works in today. Mary has worked in this district as an academic coach for seven years, and she is now in her second year at Brits Elementary School. The county provided a lot of professional development to teachers and literacy coaches. But she took her experiences, looked at what worked well and what did not work well, and that experience guides her all the time. In 2013, Mary was nominated as best teacher in the district and served on several committees for the county and state. Mary was trained in different professional development areas including writing, reading, and math, which she emphasized with her current teachers at Brits Elementary School. Mary explained that to grow successfully in her coaching career, she tried to consider her teachers' needs and avoided telling them to do something unless she has done it herself.

\section{Bob’s Learning as an Experienced Teacher and Coached by Mary}

Bob is an African American father and had the most teaching experience. He is in his fifth year of teaching, all in fifth grade. He is a certified teacher of kindergarten through sixth grade. Bob attended college at mid-Atlantic university and got a Bachelor degree in child 
development and family studies. He explained that most of his knowledge of teaching reading was strictly based on the basal series/textbook going page by page with his students. In addition, he said that he thought that he understood teaching reading, but not until Mary worked with him. Mary provided him with support and professional developments that opened his eyes. He noticed that his thoughts were always wrong because the structure and the procedure he used to teach reading were not appropriate for his students. Bob also stated that Mary’s support, increased his confidence of teaching reading. He learned that teaching reading needs a teacher who is committed and willing to learn from others.

\section{Nancy’s Learning as a Novice Teacher and Coached by Mary}

Mary is a white female teacher. Even though Mary selected Nancy as a novice teacher, Nancy is not characterized as a first-year teacher. She has been a long-term fourth grade sub teacher for six years. In 2016, Nancy officially became a certified teacher in fourth grade. Her Bachelor's degree is in elementary education and Master’s degree in learning technology. Nancy has been learning to teach reading since she met Mary at this school as a new teacher. She explained that when she started teaching reading, she could not understand what she was going to run into until she got in there, saw other people do it, and did it herself.

\section{Researcher's Role}

In conducting qualitative research, it is essential that researchers acknowledge their experiences with the investigated phenomenon and do their best to lay their own presuppositions aside to allow for rich information to emerge. In an effort to do so, I used this section to describe my experiences with the given phenomenon and to describe my experiences in education that further explain my interest in this topic. I was always aware of how my personal history and experiences shaped my perspectives about what I “know” about learning to teach reading. 
In nine years of experience in education, I began my career as a middle school language arts teacher in an environment where $78 \%$ of the school's population were defined as at-risk (students who were on free or reduced lunch) and who were not showing adequate progress in reading on the state's standardized assessment. I then taught at an elementary school with similar demographics. For four years, I worked to learn how to meet the reading challenges faced by my students. Although I majored in language education and outcome-based education, and much of my coursework focused on literacy, there was little emphasis on how to teach students to use reading strategies to better comprehend written text. Teaching reading was difficult, and I was forced to attend workshops and read more books to gain the skills I needed to teach struggling readers. During that time of my career (2000), the concept of literacy coach had not taken shape in Limpopo and Gauteng Province public schools. We did not have a reading coach, one with expertise in reading onsite. Rather, we had to figure out on our own before the district official could think of something for us.

After five years of teaching at the elementary school level, I left the classroom to become a learner support teacher. I was trained to work with students with learning difficulties in and outside of their classrooms and to observe and share ideas about instruction with teachers related to student performance and reading instruction. I became involved in various school activities such as the School Assessment Team and Language Arts committees. During that time, the district used reading specialists, reading teachers, and learner support teachers to help schools improve reading. We involved teachers in professional development, conducted classroom observations of reading instruction, and provided teachers with unlimited feedback about their students’ performance and instruction. We introduced more reading activities, reading assemblies, and rewards to motivate students and teachers. In 2008, the district built two 
classrooms: one to be used as a library and one as a computer lab. The students and parents also were motivated to be involved in all the reading activities.

By sharing ideas during group discussions and with my colleagues, I learned that some South African teachers, including me, had trouble with teaching reading, which encouraged me to become more interested in reading education courses. So I came to the United States to complete my Masters of Art degree in reading at mid-Atlantic university. My course work reinforced my sense that literacy achievement was more than a matter of finding the right strategies to teach reading. My coursework also helped me to realize that teaching reading was very challenging, especially in the South African township schools where teachers and students are very diverse and speak a number of languages. Many schools in South Africa are still operating with a shortage of literacy coaches. All of these experiences motivated me to design this study, informed by my personal pedagogical belief that literacy coaches need to provide support to teachers to make a difference in the field of teaching reading.

I recognized that life-shaping experiences related to my own teaching experience and the contexts in which I have been situated, were different from the participants of the study. I remembered how my thinking had been shaped. I also recognized that others were approach their knowing from different perspectives, and I remained open to these alternative perspectives as I attempted to bring together the divergent paths of my teaching life and the teaching lives of my participants.

\section{Data Sources and Collection}

Although there are a variety of ways to gather data, the primary data source for this study was consist of interviews with each participant. The purpose of conducting interviews was to gain "an understanding of the lived experiences of other people and the meaning they make of 
that experience” (Seidman, 2006, p. 9). In fact, “qualitative interviewing begins with the assumption that the perspective of others is meaningful, knowledgeable, and able to be made explicit” (Patton, 2002, p. 341). Thus, interviews provided an opportunity for investigators to hear other people's stories from their own perspectives and in their own voices. However, Patton warns that "the quality of the information obtained during an interview is largely dependent on the interviewer” (p. 341).

The interview was semi-structured, as this method allowed for the collection of data to be systematic (Patton, 2002). The interview guides (i.e., Appendices A \& B) included open-ended and probing questions that allowed me to obtain in-depth information related to the experiences of coaching and being coached. I asked the participants to elaborate on the experiences and to share and express their opinions as they described how they have learned and are learning to teach reading in a manner that meets the needs of students.

Because of the time and conditions when the school closed, I was limited to two interviews with each participant. The literacy coach interviews elicited how she provided support to teachers who were learning to teach reading to meet the needs of all students in their classrooms. Teachers’ interviews elicited how teachers believed how the literacy coach supported their knowledge changes related to learning how to teaching reading. I took notes that describe the context and the body language, facial expressions, and other non-verbal that were evident during the dialogue.

I interviewed the participants separately in a safe location chosen by each participant. Teachers’ preparation time was between 1:45 p.m. to 3 p.m. Therefore, the three interviews had happened to be conducted in the conference room around 1:45 p.m. to 2:50 p.m. But one of Nancy's interview was conducted in the staffroom because the usual room was occupied. 
Therefore, she decided to use the staffroom. The place was quiet and open. Two teachers came in to pick up their belongings, but they went out immediately after they noticed that we were busy. The printer was printing, and Nancy was disturbed by the conditions, but I did not allow the conditions to sidetrack our interview. I kept Nancy's attention by asking her the open-ended probing questions.

I interviewed two teachers before I interviewed the literacy coach. The first literacy coach interview took place in the conference room while the second one happened in her office. Both of the interviews took approximately 90 minutes, while teachers' interviews were approximately one-hour long. All interviews were audio taped and later transcribed for analysis. Open-ended and probing questions were asked to encourage each teacher to share experiences related to the support the literacy coach provided as each teacher learned to teach reading. The literacy coach was also asked to provide more in-depth information about her support to classroom teachers.

Following the first interviews, I prepared written transcripts from the audio recordings before conducting the second interviews. I shared the transcripts with each participant to get approval of the information recorded. The data collection cycle with each participant (literacy coach and two teachers) took place over a period of four weeks.

During the interviews, I followed Seidman's (2006) procedure for becoming a good listener. Seidman noted that listening is the most important skill in interviewing. During the first listening, he stated that the researcher had to listen to what the participants said. During the second listening, he encouraged the researcher to listen to what is not said. Finally, the researcher had to listen to maintain a consciousness of the procedural and personal aspects. Following this guidelines, I reviewed the audio tapes and transcripts multiple times. Patton speaks of this as the 
"quality control to guarantee that the data obtained will be useful, reliable, and authentic" (p. 384).

\section{Data Analysis}

Content analysis was used to analyze the data. Hsieh and Shannon (2005) described qualitative content analysis as "a research method for the subjective interpretation of the content of text data through the systematic classification process of coding and identifying themes or patterns” (p. 1278). This approach allowed me to understand truth from my participants’ responses through organizing and classifying a large number of written transcripts into an efficient number of categories representing the differences and similarities among their experiences.

Interviews were analyzed at an early stage so that I had the opportunity to move back and forth between the reading of the data and the interviews in order to better understand the participants’ perspectives. I personally transcribed all of the communications recorded. By transcribing the audio-tapes myself, I had more opportunities to listen carefully and focus on the data collected. I also used my IPhone 6 audio recorder and slowed the recorder to the speed in which I could type; I had the opportunity to listen to the interviews everywhere I went. I listened

and typed, simultaneously transcribing the words. Then I reversed the audio recorder, and re-read the transcriptions to verify the words as I listened on the audio recorder. It often took more rereadings and re-typing to exactly capture every word, phrase, and sentence spoken. I listened and re-read until each phrase spoken was exactly transcribed.

Each interview was transcribed into a Microsoft Word document and stored on a computer that was protected by a password. The text was read and re-read as I highlighted the exact words and phrases that seemed to capture key thoughts from the literacy coach and 
teachers. I looked for patterns in words, phrases, and sentences used to describe the literacy coach’s support and the teachers’ perspectives as they learned to teach reading in their classrooms. I combined the teachers' interviews and then read and re-read the data repeatedly to a coding scheme and categories from the data (Patton, 2002; Creswell, 2007).

During my data analysis, I followed the advice of both Patton (2002) and Creswell (2007) and kept the number of codes to a manageable size so I was not overwhelmed by the data. In addition, Patton (2002) suggested that the starting point of analysis is to look for "convergence or recurring regulations” (p. 465) to form categories. Once the codes are established, I read and reread again to sort the codes into categories and then organize them into themes based on the literacy coach’s perceptions, experiences, and the roles she played in supporting the classroom teachers as they learned to teach reading. A copy of the interview transcript was given to each participant to check the accuracy of the transcribed notes.

I used a blank sheet to collect, organize, and analyze the codes I developed. This blank sheet was used to identify developing themes and patterns in the transcripts and to recognize information that was connected to the research questions in the study. This system was used to simplify the information and look for similar phrases and key words that could be categorized and named as the themes that emerging from the data.

I shared the themes and interpretations with the participants for peer and member checking and requested their thoughts about the findings. This process also helped me to prepare to write up the findings. To draw conclusions from coded data, Patton (2002) stated, "Provide enough sufficient description to allow the readers to understand the basis for an interpretation and sufficient interpretation to allow the readers to understand the description” (p. 503-504). In 
this case, I provided enough description in my final written report to illustrate how I made all my decisions concerning the coding and interpretative process.

\section{Trustworthiness}

To ensure the trustworthiness of this study, I explained my efforts at ensuring quality through Guba’s and Lincoln’s (2002) language of “trustworthiness, credibility, transferability, and confirmability” (p. 13). A significant part of the discussion of trustworthiness was assured in the notion of what constitutes "truth" in qualitative research (Patten, 2002; Merriam, 1998; Guba \& Lincoln, 2002). Generally, the authors in this field contended that there was one single truth in any investigation. Merriam (1998) suggested participation, member checking, or research bias as one of the basic strategies that formulate trustworthiness in qualitative research.

Therefore, I engaged the participants in member checking by providing each of them with a copy of the transcripts and the interpretations for their review and feedback. To provide the reader of this research with an opportunity to determine the transferability of the findings, I provided a thick description of the participants and their learning communities. I provided descriptive data about each participant, their contexts, and their practices.

Regarding dependability, I created and maintained an audit trail for all documents. All the raw data (transcripts, analysis products, coding pages, and notes) were available to other committee members so they might trace the evidence I used to support the findings. In case of confirmability, I ensured transparency to all aspects of the research process and provided access to the raw data, analysis, methods, findings, and conclusions.

Not only did I safeguard the participants with anonymity, but I also worked hard to protect the data that were gathered during the study. I developed backup copies of the computer files. I locked the data in a safe, locked locker in my house, and I labeled the data for easy 
identification. In addition, I shared the data of this study only with the participants to provide the opportunity for member checking, with the members of the doctoral committee, and with one peer auditor who was willing to assist.

\section{Limitations of the Study}

There were several limitations in this study. The participants in this study were purposefully selected, which means this study was not opened to a large number of participants. The small sample size might be viewed as a limitation. Data collection was limited to two interviews per participant. Only participants and members of the dissertation committee were given the opportunity to read the transcripts of the interviews for the purpose of verification. The researcher's bias might also be a limitation, but was addressed by the participants as they engaged in member checking. Thus, this study was limited by the questions that will be asked, the small number of the participants, and the use of only one method of collecting data. Further, the sample represented the demographic composition in one county and elementary school in one small town in mid-Atlantic state. This limited the results of the study, and the results were not transferrable to other populations.

\section{Summary}

This study used a qualitative research design that included semi-structured interviews as the primary investigation tool (see Appendices: A \& B). Through creation of a thick, rich description of the research findings, analysis of data collected, and alert representation of themes found within the study, I documented the conversations between the literacy coach and the two teachers. I highlighted the support the literacy coach gave to teachers, and how each teacher described the support the literacy coach provided to help them teach reading to all the students. 
The trustworthiness of this study was supported by member checking, thick description, and an audit trail. In chapter four, I present the findings of this research. 


\section{Chapter Four}

\section{The Findings}

The purpose of this study was threefold. First, I wanted to examine how an elementary literacy coach supports (or does not support) classroom teachers as they learn to teach reading in ways that meet the needs of their students. Second, I determined how the coaching influences the ways in which a classroom teacher plans for and carries out reading instruction. Finally, I wanted to understand how the educational context influences the nature of the coaching and how classroom teachers learn to teach reading. In this chapter, data are presented in four units: biographical data about each teacher, the beliefs on how literacy coaching supported their learning, teacher beliefs on how coaching influences their plan of and carries out reading instruction, and teacher beliefs on how educational context influences the nature of the coaching and the way classroom teacher learn to teach reading. The information contained the findings for research questions one, two, and three:

I have used pseudonyms to protect the anonymity of the participants. The literacy coach and teachers' interviews were the primary data source for the explanations. Through interviews, I was able to gather the ideas about the background experiences of Mary (the literacy coach, and the two teachers (Bob, an experienced teacher and Nancy, a novice teacher) and descriptions of information on how teachers got supported, and learned to teach reading.

\section{Supporting Collaboration as Described by Mary, Literacy Coach}

Mary, Literacy Coach

A number of themes emerged through conversations with Mary about supporting teachers’ learning to teach reading, planning, and reading instruction include: beliefs in designing professional and reading instruction based on teachers' and students' needs; power of 
going into teachers' classrooms to co-teach with them by modeling specific teaching strategies;

the power of collaborating with teachers and scaffolding support from the teachers' classrooms; and the importance of increasing teachers' ideas through questions and having conversations with them about their needs and students' needs. Each theme was discussed below.

\section{Literacy Coach Describes her Belief in Teachers’ Needs}

Mary stated that she considered in considering teachers' and students' needs when she designed her embedded professional development of teachers' reading instruction. She explained that classroom teachers' needs are an essential instructional framework that helped her structure her professional development of teaching reading and helped classroom teachers understand and learn easily. Her strong belief of considering classroom teachers' needs was her evident when she talked in the interview sessions. During the interview she shared:

I also try to be really realistic because I know how hard teaching reading really is, and I try not to tell teachers they have to do something...I really ask and talk to them and see where they think their deficiencies are, or just where they want to grow. Like upper grade teachers who sometimes wanted help on the literature cycle and then I take it from there.

Mary believed that the work of the literacy coach should deal with helping classroom teachers to understand teaching of reading, which influences the planning of the practices. The power of going in the classrooms, and co-teaching with teacher through modeling the lessons or reading instruction evidenced as Mary's essential approaches. She preferred in the process of teaching reading because classroom teachers have multiple opportunities to observe, understand, and have conference or get feedback immediately. Mary believed in helping beginning teachers because she realized how important it is for them to integrate the college level knowledge of teaching reading with field practices. Through the approach, she also realized that she helped 
teachers reflect on their teaching of reading especially novice teachers like Nancy, whose name was always repeatedly mentioned in her conversations.

\section{Literacy Coach Describes Supporting of Teacher Learning}

When Mary was asked to describe the coaching activities she used to support teachers in improving reading and literacy instruction, Mary openly stated that she strongly liked to work with new teachers more than experienced teachers. She shared information about her current practices with novice teachers about professional development. Providing embedded professional development and modeling lessons in the classrooms based on teachers' and students' needs was clearly one favorite way Mary supported her teachers. Listening to her conversation during the interviews, all of her training, and professional development are performed during the school hours' days where the students are available for modelling and observation purposes.

Regarding the example, she provided of teaching guided reading, Mary explained that she began talking with the teacher about the student's reading level looking from the running records results or any topic that needed to be addressed. She also explained that she collected information about what the classroom teacher already knew about the specific topic they would work on. The next step Mary stated that she would go in the teacher's classroom and make the teacher watch her teaching, and then, they both co-plan using the running records information assessment the classroom teacher made to determine the correct instructional level a student should be working on. They both chose the book on that level and matched with the student and others of the same level.

Furthermore, Mary shared “I modeled for the teacher by taking a picture walk through the book with the group of students first. On the way, I stopped and pointed to a tricky word to a student, and the students would whisper read as I listened, and made observations. Then, I 
discussed the text, took information from observations, and provided a quick mini-lesson to correct any misunderstanding”. Mary stated that she liked doing that because she realized that it was important for classroom teachers to see her working with students, especially students who have difficulty understanding reading skills. She also helped them make some connections to the professional readings. In addition, it was Mary’s evidence that she needed classroom teachers to understand learning how a teacher's action could make a difference in how students learned. In addition to the first support, Mary explained:

I asked them firstly where they feel like they need help. Newer teachers get to interact with me a lot, and they are definitely a focus especially at the beginning of the year, which was a case with Nancy last year. She was a new teacher at our school and so I gave her support virtually the whole year. I try to give new teachers support... I go in and model writing lesson with the teachers especially because this year has been a very big year for writing for us. Our school purchased a new curriculum. I work with them on getting their kids assessed. I helped get their routines, organize and set their centers up. I help them look at their children's reading levels, and we form their reading groups based on those levels. I also work with math teachers in their math instructional practices, and also reading interventionist. We pull kids for reading interventions.

Mary indicated that she was not an expert in teaching reading, and she liked to learn from others. When she was asked about what she used to help teachers who experience difficulties teaching reading. Mary said that she is an "go to and get person". She is open to her teachers to try new things and learn from others because she is not an expert to all teaching. She first let the classroom teachers tell her where they have strengths and weaknesses but if the problem is difficult to her, she sometimes provided teachers with opportunities or freedom of learning from their colleagues. Mary shared this:

Sometimes I'll send them to another teacher. I'll come watch their class. We had a brand new kindergarten teacher this year... Well, I'm not an expert in kindergarten. I can give her basic tips, but she really needed to see it in action. So I taught her class. I watched her class. So she could go watch this masters' kindergarten teacher's work...their magic to teach reading. So sometimes it's that 
I let a teacher go, let her or him watch this person, because they have a fabulous way that they do.

Another support that she provided to teachers was intervention that she used to help students who were identified at risk in reading. With the support of the teachers, they both decided whether the student would be in the intensive or strategic group. She was in charge of looking at the students' data and also helped teachers to monitor and decided who was going to move out of a group or to a different group. She also said, "I support teachers with the professional development in the classrooms and outside of the classroom.” She was everything to her classroom teachers and to the school in general because she met the requirements for being a Title 1 school.

\section{Supporting Collaboration as Described by Teachers}

When analyzing the two teachers’ interviews, I discovered several common themes.

Teachers believe that Mary, the literacy coach, supported them by giving them feedback, and giving them opportunities to learn how to group students using the information from the running records. They were provided with opportunities to try new things like the Daily 5 approach. She provided them with opportunities to come into their classrooms and have them observe her modeling reading instruction with their students. She used to co-teach with them during some of their lessons. She found resources to help them be confident to teach reading. She helped them to understand how to incorporate students' interest into their practices, how to choose reading materials, and how to provide students with the freedom of choice when coming to learn how to read. Last, she helped them understand how to collaboratively work or share reading ideas with their colleagues. I have highlighted, through quotes, the foremost themes. 


\section{Bob’s Descriptions of the Literacy Coach’s Support of Teacher Learning}

Bob was an experienced male teacher. From the beginning of the interview, I asked Bob about the support he got from the literacy coach. With a big smile, he responded, "Mary really opened my eyes as opposed to trying new things, and she does a really good job of researching different ways of doing stuff. She's pulling from other teachers and just presenting to the teacher to such an extent that is really encouraging a teacher to try. One of the things that we've used that's really stuck to me for our reading is the Daily 5 Café approach. Mary helped me with my struggling students when she provided them with different reading skills and strategies.” Listening to Bob’s responses about the word "really" that he repeatedly used when describing Mary’s support, it explained that Mary was a “really” outstanding literacy coach to her teachers. Bob’s interview showed how significant it was to have support from the literacy coach in schools while teachers learn how to teach reading. When I asked Bob to explain things the literacy coach did with him. Bob reported:

Really it kind of depends on what we're doing. She mostly focusses on the newer teachers, but when she's been in my classroom, it's been lately for being a writer program. I've had her at the beginning of the year quite a bit, approximately three times a week last year when I first integrated the café. She found us an awesome program to teach writing. So she came in and we actually go do a lesson together. We went out almost like a co-teach where I'd come in and talk a little about it and just kind of back and forth helping the kids with it. It's really interactive modeling.

Bob’s acknowledgement of the literacy coach was clear as he described in detail how much he had learned since last year after the literacy coach worked with him a couple times. He felt confident especially when he noticed his students' writing improvement. When Bob looked at his students' writing progress from the beginning of the school year until now when the 
interview took place, he mentioned that he saw "two different worlds" from his students. Bob shared:

I mean my students performance, that's it's across the board for my guys...so I think just having her there for those times...there really helped and the kids are much better writers because of her and the program she introduced to us.

Bob’s responses also indicated that Mary did not provide support only to teachers and let them go away; she also considered students. When I listened to the remarks carefully, Mary preferred to be in the classroom with teachers and modeling something to promote reading. She also liked to work with students all the time. Bob did not want to stop admiring the literacy coach. He shared how she came into their rooms and worked together with the classroom teachers and students, modeling lessons or reading instruction together. Bob stated that Mary helped him to know how to do the running records even though he was still using some of the reading assessment he learned from college. He continued to state that the support the literacy coach gave him, made a huge difference in how to teach reading. Bob explained how his knowledge increased in the importance of teaching read-aloud through Mary’s support. Bob said that she helped him to know how to breakdown the reading-aloud activities into a pieces of fifteen minutes where the students had a choice of what they wanted to do, such as reading to someone, to themselves, or listening to reading. The other comment Bob made took us back to the beginning before the literacy coach intervened. He was struggling with how to start teaching reading because he thought that it was easy to use the textbook and focus on reading page to page to teach students. But now that his eyes were opened, he was confident because he learned how to put his resources together like finding more reading materials that students want, finding interesting stories for the students to read, and making a mini-library in his classroom for his students to read. 


\section{Nancy's Descriptions of the Literacy Coach's Support of Teacher Learning}

Nancy was a current novice female teacher. When I asked her to describe how the

literacy coach supported her, with her smile, Nancy was provided lots of stories and memories of Mary. Nancy shared:

I was lucky to work with her...she was a huge help to me last year as a long-term sub in fourth grade. Mary got me into doing the Daily 5 approach. She came into my room a couple times in a week and helped me run the workshop...she helped me figure out how to run the stations and how to group the kids, just launched the whole thing right there, in my room, with me, and then once we got it launched, she come less and less until I was on my own but she set me up, with that big time. She also helped me know the running record and how to do that.

As I listened to Nancy pondering about how the literacy coach supported her, I began thinking of Bob’s acknowledgements and started recognizing the value of Mary at that school. I pictured her as an "go to get” person for anything connected to literacy or teachers' and students' needs. Nancy stated that Mary worked with the students. She also did professional development and attended their professional learning committees held once a week per grade. Pretty much everything that teachers needed help with, Mary provided help or was available when they asked her something. She would figure that request out. If she did not know anything about or was unsure, she did not hesitate to help them figure it out, get them resources related to the problem, or recommend a teacher who had knowledge about the problem. Listening to the teachers’ comments, I found Mary meeting the literacy coach's requirements described in IRA (2004). The literacy coach required to document positive outcomes for student achievement. She had to be experience working with teachers to improve their practices; and be excellent presenter. She had to be skilled in leading teacher groups and facilitating reflection. She needed to have in-depth knowledge of reading process, and have experience that would enable one to master the complexities of observing and modeling in classroom and provided feedback to teachers. 
Nancy stated that Mary came in to her class a few times and then "once we got it launched, she came less and less until I was on my own, but she set me up with that big time.” Nancy's statement showed that the literacy coach provided support to her teachers more times until she was quite sure that everything was stable or understood. Later, she scaffolds herself from coaching instruction from the teacher's classroom, but she did not forget about the teacher. She sometimes visited to make the follow ups and check if the instruction or strategies were still properly provided in the classroom and provided feedback to the teacher.

\section{Literacy’s Coaching Influence of Planning and Enacting Reading Instruction}

During the interviews, Mary was asked about things that influence her coaching in the teacher's planning and carrying out the reading instruction, and then Mary repeated her point that her coaching was influenced by collaboration based on teachers' needs. She shared this:

I attend all teachers' professional learning committee meetings one time a week, and so I attend those and listen to what they're doing in the classrooms, what standards they're working on, and then that helps me in turn decide how I can come into support them in planning... So just listening to what they need, helps drive what I go in and do. Now sometimes the county will have an initiative. For example, this year our county adopted a new basal series... So it can be teacher driven, but sometimes it's county driven. If the county has something they want me to go in and provide professional development on, then I do that.

During the interview I asked her how she attended their meetings, and she responded that each grade holds professional learning committee meetings, and she made sure that she attended those meetings to listen to teachers' strengths and weaknesses. I asked her what would classroom teachers be discussing in these meetings, and she shared that it depended on the teachers' common problem in their grade level, but she gave an example of comprehension strategies. She explained that a group of teachers worked together to plan each part of the lesson, sharing reading strategies that work for them or that did not work. They selected a book that would meet 
the needs of all the students. She also shared that sometimes they met together to discuss the standards that would be used to teach students.

When asked about things that influence coaching in reading instruction, Mary was not ashamed to say that she used some of the experienced teachers to help other teachers who needed help that she could not provide. She also mentioned that she was using some of the literacy based ideas she got from her previous teaching experiences and some that she received from the training she got while she was working from Fairfax County. Mary said:

I would say my time as a classroom teacher. Those have been the most valuable experiences that I draw upon because I've done it myself in a classroom, and I know the challenges that a classroom teacher has when trying to meet all the different needs of so many different readers in the classroom.... and I try to be really realistic because I know how hard teaching really is, and I try not to tell teachers they have to do something unless I've done it myself or willing to go in and model it for them.

When I listened to Mary's statement, I realized that she is a literacy coach who still based her teaching, professional development, and instruction on teachers' or students' needs. She was sure to say that her teaching experiences and her ideas professional development sessions guided her reading instruction because she used those to look at what worked and what did not work well. She built her coaching from there.

In addition to the literacy responses about coaching that influence classroom teachers’ planning, several common themes emerged from teachers' perceptions: planning based on the county's text, the implementation of the Daily 5 approach, learning from other teachers through observing their teaching practices, using students' needs and data to scaffold their teaching, and learning from professional development. According to classroom teachers' responses, they followed the Daily 5 approach used by teachers at the school. They believed that the program helped them plan their lessons and practice their 
instruction successfully because the program continued what students learned from the early grades and continued to other grades. They also stated that they used students' data to redesign lessons and to implement the instruction.

A question was about how to plan the activities they do with Daily 5 approach. Both teachers describe that the students got free choices because the students had the opportunity to work in rotating stations. This allowed them to work in groups where they read to themselves, read with their partner, worked with their words, worked on writing, and shared their writing with others in groups or the whole group. Bob stated that if he saw students struggling during the stations, he quickly turned a problem into a minilesson for fifteen minutes and worked with the students who were affected. In the Daily 5 approach, teachers explained that students were given the opportunity to know what skills they would be working on and were assigned to work in small groups. Reading freedom is practiced in the Daily 5 approach.

\section{Coaching Influence on Bob’s Planning and Reading Instruction}

Bob conveyed that the academic coach and the administration helped him to organize his planning and reading instruction because they always allowed him to try new things in his teaching. Bob specified often his planning was based off the county's text or students. He gave an example of when he realized that they struggle with something, he quickly gave mini-lesson for about fifteen minutes and focused on the problem. He tried to go back and forth with the students stressing what they had in the past, or he used the ideas he got from his colleagues during professional learning committees meetings. For planning his instruction with the Daily 5 approach, he reported that he quickly did the mini-lesson, and then sent the students to small groups, or the whole group. The other thing he used to practice was getting books based on their 
levels and working with them. Bob even said that this Daily 5 approach setup is something he liked because he did it in third grade and he continued with it in fifth grade. It worked for him.

\section{Coaching Influence on Nancy's Planning and Reading Instruction}

Nancy stated that she followed the guidelines from the adopted text because the planning had the right guidelines on what skills to work on. During the activities, she allowed students to work on the same thing while she focused on working with lower students. Nancy stated that they worked on the skill selected a little bit with the adapted text, and later she built on it in small groups. She also stated that she used some of the ideas she learned from her literacy coach when she paid a visit in her classroom. I asked Nancy about things that would be the focus of the literacy coach and her interactions when she visited her in her classroom. During the interview, Nancy mentioned that Mary was always there for her in the classroom planning. Nancy said:

She comes in and we kind of do a teaching it together like we both have the manuals and the materials. We'll know what lesson we're doing. One day she'll take over and teach it a little bit for me while I'm conferencing with kids or I'll teach a short float around and check on the kids and see how they're progressing individually. So we kind of just team up the new lessons together and she'll give feedback on what is going well or what other teachers have tried that are already done to what I'm doing. As I said, this is my first official year of my teaching.

As I talked with Nancy, I was struck by her confidence, honesty, and learning spirit. She said that she depended on the literacy coach for support throughout her first official year of teaching fourth grade and that she used what she learned from the literacy coach to build her teaching standard. As stated above, team work between the two was very strong. For her reading instruction, Nancy stated that she preferred freedom of choice with students. She let student to be independently by picking their own books they wanted to read to their own level and their interests. Nancy used the strategy to build on 
her instruction. She gave an example of the students being interested in the primary elections. Their story was focused on voting, the right to vote, and women's rights. Nancy was brave and proud about teaching reading through the support she got from the literacy coach. I was interested when Nancy explained how she learned to group her students through the help of the literacy coach. She said that before she got support from the literacy coach, she used her own observation and students' classroom work to group instead of uniformed assessment such as running records. She explained that she grouped her students primarily based on their most recent running records, putting students together with others on a similar guided reading level. According to Nancy, the groups change depending on student progress. The student could be moved from one group to another or moved to an Individualized Education Program (IEP). She also mentioned when they worked together with the literacy coach, she was busy conferencing with students.

For conferencing with the students while they co-taught with the literacy coach, Nancy was asked if conferencing actually changed her practices and if she used it as an assessment to plan the lessons or strategies. Nancy also explained that it changed her practices because she used it to meet with the kids to discuss their individual work and strategies. Nancy stated that during the conferencing, the student set personal goals to work on when working independently. Nancy said that conferencing was one way to check in with each student's progress and needs on a one to one basis. When Nancy was asked to describe any improvement after she got support from the literacy coach, Nancy did not have any trouble answering the question because she had enough time to do things together with the literacy coach. She said that Mary was helpful because before 
Mary came, she was stumbling through the basal book. So the literacy coach helped her to understand literacy instruction by setting her out more about the workshop type basis where she learned that "there are more free reading choices for the kids in teaching reading” Nancy stated that she saw a tremendous growth in the kids last year. She also mentioned that there was one teacher who was her official mentor. She said that the classroom teacher helped her out by sharing some ideas, but the teacher was not as helpful like Mary because she had her own classroom to teach, so she preferred someone who could come in the class and be with her to get things going together like Mary.

Nancy did not stop acknowledged the support she got from Mary. Nancy said that Mary was not helping her alone in the classroom, she was also increasing her support to her students. Nancy explained that when she worked with the struggling students, Mary worked with one of her higher group students studying a piece of novel. Nancy said, "She definitely helps with the students and she gets right in there with them” From these two reports, the points evidenced how Mary was fully involved and contributing to literacy coaching areas across the school. Mary mixed traditional and new professional development in her teacher support while helping teachers to learn or understand the teaching of reading.

\section{Educational Context Influence on Coaching and on Teacher Learning}

One feature of the literacy coach's role is to support teachers' learning. However, there is another important role of the coach: to increase students' learning. These two aspects need a literacy coach’s support. When Mary was asked about educational context that influenced her coaching, she mentioned conversation and a good rapport with her school principal. She stated that her principal was open and supported what she thinks would work to increase literacy 
practices and students' progress. Mary also reported, that: “I talked to other literacy coaches and kind of listen to how they work with teachers and see what they feel like works for them." Mary also stated that she tried to be abreast of new things by reading about professional development from books, The Reading Teacher, and different Magazines. The other points Mary noted were the new program of "Being A Writer" and the literacy intervention series by Fountas and Pinnell (2003) which are recognized national wide. She also stated that Maruel County provided different professional development every time. Collaborating with her teachers based on their needs, her experiences, and enacting instruction with teachers in their classrooms were the main aspects mentioned during the conversation with Mary. When I listened to Mary talk about how the education context influenced her in the coaching area, it was evidenced by her support and how she was fully involved and contributing to teachers' learning at Brits Elementary School. Mary was also influenced by involving the parents or community members in the students' learning.

Regarding how educational context influenced classroom teachers' learning, Bob shared: "I would say academic coach because to me I always thought reading was okay, but just working with her and having the opportunity to work with her, it's really given me more understanding in teaching reading." The other part that Bob mentioned was the one Mary stated of the administration who were open to all the classroom teachers when they were given opportunities to try new things in their classrooms and at school in general, and on top of that kept on providing support and feedback. According to Bob, different professional developments and learning from other colleagues were also viewed as the main tools of learning because there was chance of talking and sharing ideas during the meetings. 
Nancy was also asked to describe how educational context influence her learning to teach reading. She supported the statement mentioned by all the participants for learning through getting opportunities from professional development. Another point she mentioned was related to what Bob said because she shared that she learned more easily by seeing what other people do, getting in the classroom, and doing things hands on. Nancy is a classroom teacher who learns better by observing other people doing things before she can understand or stand by herself. I asked her to describe the type of professional development she wished to have at school, and this is what she said:

I guess for effective professional development; it would be much better if just be implementing things that we practice in the classroom. For example, things like reading articles, books, or stories in groups and have discussion about them. I wanted effective professional development that would make someone see and understand how other teachers implement these in their classroom and has more to do with how to actually make teaching reading work in the classroom. I wanted a professional development where we will get visit to a classroom and watch somebody do the lesson or the book and see how the students react to it, and then later go back and talk about it. That's the most valuable thing to see it in action rather than going to a big meeting told like this is your new writing program. Here it is, have fun, and go teach it and later no one come and watch whether you are doing well with your teaching.

Nancy was also influenced by curriculum adopted by the county and by the state standards that encourage classroom teachers to have a similar planning, skills, and strategies at the same time. Talking with the literacy coach and other teachers of the same grade and deciding together what they were to cover, were found to be supportive and influential aspects in learning how to teach reading. Nancy had more stories because according to her, everything that is going on in the outside world (current events, students' interests or needs, their missing comprehension, and certain strategies that need her attention) was educational context that influenced her learning to teach reading. Nancy was confident about the support she got from the literacy coach. I asked her to think of a missing part in her teaching that she thought she still 
wanted to learn about and that she thought could help to increase her learning and students' reading. Nancy thought of adding novel studies and a literature circle in her learning to teach guided reading. Teachers were asked to look back to where they started teaching, compare their teaching now after they worked with the literacy coach, and tell if it is necessary to have the literacy coach in each school. Both of them supported the idea of having a permanent literacy coach in each school because they noticed that the help and support they got every day would not be able to be spread over three to four schools. Bob stated that since teaching reading is so complicated, it needs teacher support from a literacy coach who understood reading and math.

\section{Summary of Participants}

My goal in this study was to understand how teachers learned to teach reading and how a literacy coach supported teachers from the teachers' and the literacy coach's viewpoints. The literacy coach and teachers were purposefully nominated based on their training and experiences. From their viewpoints, I learned that they both collaborate in the sense of improving students' learning and also increasing their knowledge to practice their instruction appropriately. From the data analysis, I learned that the teachers' viewpoints of the way the literacy coach supported them and the way they learned how to teach reading were significantly different but from some of their viewpoints, they were learning and supported equally. I believe this was because of their experiences and also the literacy coach's decision. Due to data analysis and understanding of experiences and professional development training the literacy coach obtained, she had a strong understanding of supporting teachers' learning to teach reading. She also considered teachers' and students' needs when she organized professional development and reading instruction. In addition, she used her experiences and understanding of the reading process to model or co-teach some of the lessons with teachers. She made herself available to her teachers all the time in their 
professional learning meetings and wanted to know their deficiencies and knowledge about their teaching by asking them simple questions. Based on the data explained, her first basic approach, was to know, to understand her teachers, and to design professional learning of the teachers guided by their needs.

Joyce and Showers (2002) indicated that utilization of coaching involved working collaboratively, providing feedback, encouraging peer team to observe one another's teaching, and having influence on coaching and on embedded professional development. Marz, Algozzine, and Watson (2008) stated that the literacy coaches currently engaged in activities such as modeling lessons for teachers, observing teachers at work in their classrooms, mentoring, gathering materials for classroom use, and developing professional learning for classroom teachers. Therefore, the most common themes that came from the interviews as the ways of showing support to teachers were as follows: collaborating based on teachers' and students' needs; co-teaching, coming in the classrooms and modeling the lessons and instruction; and providing feedback and embedded professional development. From the interview responses, it was demonstrated that all teachers were more confident when teaching reading and implementing new things in their classrooms after they worked with the literacy coach. The next section I discussed in this chapter was the comparison of the novice and experienced teachers.

\section{Bob (an Experienced Teacher) and Nancy (a Novice Teacher)}

The data analysis consisted of noting the differences between how Bob (an experienced teacher) and Nancy (a novice teacher) got support from the literacy coach and what they learned that can help them meet the needs of all the students in their classrooms. In the interviews, Bob indicated his appreciation of the presence and support of the literacy coach while he learned to 
teach reading. Bob described that the literacy coach's support was less because she focused her support more on new teachers.

Nancy was more informative than Bob with the support and learning information. For example, when I asked him what he learned, Bob pointed out that he learned how to try new things through the motivation of an academic coach; how to integrate the Daily 5 approach in the teaching of reading; how to do the running records. Bob reported that he also learned how to coteach; how to reflect on students' data to adjust the reading instruction and planning. He also indicated that he learned how to plan reading instruction based on students' interests; how to give students more reading and writing opportunities; and how to provide students with freedom of choice in reading. Nancy stated that she learned how to run the stations, to group the kids, to launch the reading program, to collaborate with other teachers by sharing ideas during professional learning committee meetings, to plan reading instruction based on the students' interests, to provide students with freedom of choice when selecting their reading materials, to co-teach, to do conferencing with the kids, to model reading to students, to teach guided reading approach and create mini-lessons for individuals. In the interview, Bob was asked to describe things or ways he thought he could teach reading, and this is what he said:

I like what I'm doing and the way I'm doing it. I really like it right now. I really like it because I did it in the third grade and I brought it down with me to fifth grade and it works. Unless Mary literacy coach comes out with something new, something that's new and better, I'll give it a shot. However, I do like it this way.

Analyzing Bob’s statement, I was so confused because somewhere in the interview responses, he stated that he learned how to try new things through the motivation of an academic coach, but the statement contradicted the point because it goes against change towards a person who is in charge. 
Nancy, a novice teacher, wished to have or add more to what she had in guided reading. She stated that she wanted to add novel studies and a literature cycle in teaching reading because she noticed that there are more novels on the shelves, but students were not reading them. Nancy opened doors for change and was willing to grow learning with her students. Bob’s statement also made me think of Mary's statement that some of the experienced teachers did not open doors to try what she was doing because they were comfortable with what they thought was good, not thinking of their students' needs. Coming in, co-teaching and modeling were the approaches a literacy coach used with her teachers when she helped them learn to teach reading. During the interview, Nancy was asked if she saw her success in teaching reading to her students after she had been coached. She was confident, overwhelmed, and appreciative of the support she got from the literacy coach because she saw a tremendous growth in her students' reading level and in their interactions and how they were able to put their words into writing, which is linked to their reading. Nancy was more informative because she was one of the novice teachers with whom Mary spent most of her time. As she explained, Nancy learned more things than Bob. Mary believes in working with the novice teachers as early as possible because some of these teachers stepped into the field of teaching confused and fearful of teaching their own classes. She also gave an example of incorporating guided reading, especially teaching phonics, because it is hard for many novice teachers. They do not have knowledge or confidence when teaching those at an early stage of reading. Some of the new teachers do not have a good background, and they do not know how to level the kids and match instruction to the level of their students. So she reported that she provided support in those kinds of background to help them learn and perform by themselves in their classrooms. 
However, for experienced teachers, she stated that she liked to help them, but they were still closing their classroom doors for her except Bob. She stated that she noticed that some of them used effective reading approaches, but some were still using the basal readers where they follow each day's plan and do not look at their kids' needs. In that case, I asked her opinion on what she thought she would do to assist them. Her suggestion was to use novice teachers' classrooms to model teaching reading, and make sure that she encouraged novice teachers to discuss or share what works for them in their planning and instruction at the professional learning committee meetings. She also thought of issuing a survey at the end of every year to get their opinion to help her build a good rapport with those who are still resisting change and plan professional development. She also thought of using the principal to get into their classrooms because she believes that they do not know her. They might be they would be open to her if the principal gets involved. According to Mary's responses, she prefers working with the novice teachers and the experienced teachers if they could give her chance. Going in the classrooms, modeling lessons and instruction based on teachers' needs, and co-teaching were her favorite approaches.

\section{Summary}

In this chapter, I discussed the findings of this current research about how the literacy coach supported teachers while they learn how to teach reading to meet all the needs of the students. I also discussed how coaching influences the ways in which a classroom teacher plans for and carries out reading instruction. In addition, I reported the findings how the educational context influences the nature of the coaching and how classroom teachers learn to teach reading. I provided a thorough description of each participant to capture the background of experiences, opinions, and beliefs in the study. In overall, the findings indicated that the importance of 
advanced education in reading, determine the power of support of a literacy coach helping classroom teachers into learning, planning of and carries of reading instruction that help improve students' achievement. In the next chapter, I summarize the key findings concerning the support the literacy coach provided to teachers while they learn how to teach reading, and how the findings relate with the literature. I finally discussed how the findings set an understanding with further research information in this study. 


\section{Chapter 5}

\section{Discussion of Findings}

Teachers today in the United State are searching for resources to use to advance the quality of literacy instruction and increase student achievement (Snow, Burns, \& Griffin, 1998; IRA, 2004). One main approach that has some value is successful on-site, job-embedded continuous professional development (Taylor, Pearson, \& Rodriquez, 2005; Joyce \& Showers, 2002; Biancarosa, Bryk, \& Dexter, 2008). The other approach that has been reinforced by the research is the use of a school-based literacy coach to plan and direct this professional development (Taylor, Pearson, Petersen, \& Rodriquez, 2005; Poglinco, Bach, Hovde, Rosenblum, Sanders, \& Supovitz, 2003). These professional development plans that use of a literacy coach depend on the coach to create a learning-rich environment for teachers and for students.

Literacy coaching is an increasing development in American education that aims to let classroom teachers observe instruction practices carried out by a more experienced teacher and to implement the practices in their own classrooms. According to Bean (2004), literacy coaches help classroom teachers implement instructional strategies and become more effective literacy teachers. However, there is a lack of research on how literacy coaches might support teachers in improving their reading instruction to meet the needs of all learners (Dole \& Donaldson, 2006; IRA, 2006; Deussen \& Buly, 2006; Vogt \& Shearer, 2007).

Therefore, in this study I focused on understanding how an elementary literacy coach supported teachers as they learn to teach reading in ways that meet the needs of their students. Second, I wanted to examine how the coaching influenced the ways in which a classroom teacher plans for and carries out reading instruction. Finally, I aimed to understood how the educational 
context influenced the nature of the coaching and how classroom teachers learned to teach reading. The discussion of the findings addresses the research questions, explaining how they align with the literature and extent knowledge based on the support the literacy coach provided support to teachers. In addition, I explain how the findings set an understanding with further research information in this study. It is essential to state that because of the limited number of one literacy coach and two teachers, the data collected will not be generalized even though their perspectives highlight the variety of support, learning, planning for and implementation of reading instruction that others might describe as a way in which literacy coaches could support or influence both novice and experienced teachers while they learn to teach reading. The findings also demonstrated the rich complexities involved in literacy coaching and the teaching of reading.

The primary roles of the literacy coach are to work with teachers in their classrooms, to model how to teach reading and writing lessons to teachers, to observe teachers while teaching reading and writing activities and provide immediate feedback, and to support teachers as they learn new things (Bean \& Swan Degan, 2012; Dole \& Donaldson, 2006). The study of Poglinco, Bach, Hovde, Rosenblum, Sanders, and Supovitz (2003) explained that the rationale behind having a literacy coach is rooted in research on creating an effective professional development environment, one characterized by providing ongoing support to teachers and creating a learning community that includes structures for focusing on instruction and curriculum. These authors found that changing teachers’ practice is grounded in the coaches’ pedagogical knowledge of literacy processing and is founded on collegial trust. IRA (2004) stated that a literacy coach needs to serve as a resource in the area of reading for teachers; to work cooperatively and collaboratively with other professionals in planning programs to meet the needs of diverse 
populations of learners; to provide professional development opportunities at the local and state levels; to provide leadership in student advocacy; and to provide specialized reading and writing instruction, in cooperation with other professionals (p. 7).

The findings of this study, support the previous studies because teachers indicated that they value the literacy coach and all the knowledge and support she provided. According to teachers' responses, the literacy coach provided ongoing support in the planning of and carrying of reading instruction and in teachers' learning. The findings on the teachers' and literacy coach's perspectives would be discussed and be linked with the relevant literature discussed in chapter 2.

\section{Literacy Coach Support to Teachers}

Lyons and Pinnel (2001) described a literacy coach as a professional developer who will "introduce, describe, and demonstrate topics in class sessions and then be able to provide direct assistance and coaching in classrooms” (p.52). Poglinco, Bach, Hovde, Rosenblum, Sanders, and Supovitz (2003) stated that literacy coaches need to be excellent reading teachers who teach on teachers’ or students’ level. A literacy coach has in-depth knowledge of processes, assessment, and reading instruction, and has experience or preparation that enables the coach to model, observe, and provide administration and feedback. The findings from this study support the role that Mary, the literacy coach performed and how the two teachers learned to teach reading in their classroom. The literacy coach in this study shared examples of the opportunities for collaborative and ongoing development she made in literacy training. She repeatedly went into teachers' classrooms, co-taught with them, modeled some of the lesson to teachers, provided professional development, and provided immediate feedback to teachers’ instructions. In 
addition, she reported that she attended phase-level professional learning committees every week and listened to teachers' concerns and used them to create her training.

Analyzing all the support the literacy coach performed, I found that she matched the literacy coaches' descriptions outlined by other researchers (IRA, 2004; Bean, 2004; Dole \& Donaldson, 2006). Therefore, the data indicate that the literacy coach at Brits Elementary School supported teachers by using teachers' needs and by modeling instruction to promote literacy practices and increase teachers' knowledge of teaching reading. The statement was supported when a novice teacher described a "go to" person for teachers because she asked teachers about where they needed support. After that, she was willing to go into their classrooms, plan together, and model the lesson while the teacher watched. Another finding was that literacy coach at this school supported teachers by searching for literacy resources to promote their reading instruction for their students or literacy resources to help them understand teaching reading. It was also found out that the literacy coach helped teachers to understand the running records and how to use them to group students according to their reading levels.

In teachers' responses, they were enthusiastic to learn from the literacy coach through coteaching, watching a literacy coach modeling reading instruction, and opening doors for her to help them learn new programs such as the use of the Daily 5 approach, running records, and Being -A- Writer to promote literacy around the school. According to the teachers' responses, the literacy coach used theoretical and hands-on practices with teachers. Through her support, she used a combination of traditional and newer professional development approaches to help teachers understand the process of teaching reading in their classrooms. During the literacy coach interview, she was asked to review the goals of her coaching to move forward with the support. Rather than being content with the wonderful support she provided, her response 
indicated that the literacy coach still struggles to go into some of the classrooms to provide support, especially with veteran teachers who reluctant to ask for help or to acknowledge that they need support from the literacy coach. Just imagine if these teachers could open doors for their classroom to allow support for teaching reading or allow opportunities in a context of teacher learning; what might occur in the process of teaching reading in this school? Integrating more reading opportunities and differentiating strategies to students' learning is essential and encouraging, but Rogers and Rogers (2007) stated that only a teacher can make a huge different in this areas of teaching. Therefore, this issue deserves much more study on how these veteran teachers could be encouraged to work with a literacy coach or open doors in their classroom for other professional opportunities to accept change in teaching reading.

\section{Teachers Explain the Support the Literacy Coach Provided}

Bean (2004) indicated three levels of coaching. Level one includes having informal dialogue, providing materials, and finding instructional needs for teachers and students. Level two described having a literacy coach who is a knowledgeable who supports co-teaching, coplanning, and analyzing data to improve students' learning and reading instruction. Level three includes visiting classrooms, modeling lessons, and providing feedback. In this study, all three levels were offered to teachers and were conducted based on teachers' needs. Collaboration between the literacy coach and the two teachers was in an appropriate way that encouraged each classroom teacher to reach a higher level of understanding about how the practices are modeled and how quality classroom instructional procedures improve students' achievement. The collaboration between the literacy coach and teachers was evidenced multiple times by teachers' response when they shared that the literacy coach was always coming in their classroom, was teaching together and was available for everyone. During teachers' interviews, when asked to 
explain how often the literacy coach provided support in the classroom, it was found that Mary used a different style of supporting. She supported teachers according to their experiences and needs when she provided support several times in a week for a year to Nancy, a novice teacher, but scaffold her support more this year (2016) when she noticed that Nancy's students can work together to read a mentor text, explore, discuss, or share their writing.

With the experienced teachers, it was found it being challenging and difficult because the literacy coach focused a lot on newer teachers. It was noticed by the experienced teacher, Bob, which takes me back to the literacy coach's comment about the behavior of the veteran teachers. It could be a challenge when veteran teachers do not open doors for help. Bob shared that "she is really focused on the newer teachers. But I had her at the beginning of the year quite a bit, approximately three times. Last year when I first integrated the café, I had her a lot. Like I said she's been helping newer teachers.” Therefore, the literacy coach needs to consider all teachers' needs equally and needs to accept their opinions and encourage their involvement by sharing or have discussion on their needs during the weekly or monthly meetings.

Another finding from this study is that Mary used her ability as literacy leader because the two teachers asserted that the literacy coach was there as their supportive colleague. They also said that she was there to offer support by incorporating new practices into their classrooms. According to teachers' interview responses, it was also found that Mary was not a practitioner who tells her teachers what to do, but she was always there to ask and support learning and development based on teachers’ needs. During teachers' interview responses, Mary was aware of the established literature about reading, literacy development, and best practices for state and local policies because during her interviews, she said that she had county-level responsibilities for providing professional development. 


\section{Responsibilities of the Literacy Coach}

Teachers in this study revealed that the literacy coach was knowledgeable about the teaching reading process, assessments, reading instruction, and students' needs. The teachers also said that the literacy coach always came to their classroom, co-taught with them, modeled the lessons and reading instruction, watched them teaching, provided immediate feedback on their works, worked with students in the classroom, provided professional development for teachers, analyzed students' data, and searched for resources for them that relate to literacy. The teachers' comments about the responsibilities of the literacy coach at Brits Elementary School relate with some of the literacy coach roles information in the previous studies (IRA, 2004; Bean, 2004; Poglinco, Bach, Hovde, Rosenblum, Sanders, \& Supovitz, 2003; Dole \& Donaldson, 2006; Bean \& Swan Dagen, 2012; Toll, 2008), and the information also relates to what Mary stated when she was asked to describe her responsibilities around the school as a coach. In addition to what all teachers said about her, she shared:

This is the Title 1 school. So I'm in charge of all the Title 1 literacy requirement including one big component of parent involvement where we train parents after school in the evening and provide them with the strategies they could use at home to support their children. I'm in charge of providing embedded professional development in classrooms where I go in and model professional development but then I'm also in charge of professional development outside of the classroom which is offered to teachers several times during the year about anything that they would need help with not only reading, but also writing...I also have county-level responsibilities that I would have to adhere to and really what my principal and vice principal decide that I need to do.

IRA (2004) argued that the literacy coach needs to have previous teaching experiences

and a Master's degree specializing in reading courses. But in this study, there was no doubt that the literacy coach had more training at the university level, and had more teaching or literacy coaching experience. Mary was a resource, supportive and knowledgeable to teachers, students, and the school's needs. Nancy a novice teacher who worked with the literacy coach for a year, 
shared that the literacy coach met with her several times in a week. She helped her learn how to teach guided reading, to group the students, to run the workshop and stations, and to learn implementing new things like the Daily 5 approach that is used by all teachers in the school. She also explained that she even helped her to use the running records. Nancy explained the responsibilities of the literacy coach, and she said that she was overwhelmed and thankful to have her in her class because she further shared:

Pretty much anything that we can think of literacy base that we need help with, we ask her. She will figure it out, but if she doesn't know or is unsure, she'll find us resources to help us figure out what we're wanting to do. Sometimes you can say "hey something in my classroom is not really working. Can you come check it out and see what I can change to make it work better?” and she'll do it just ...I don't even know what else to say.

Mary was flexible to her teachers around the school. Bob also revealed that the biggest thing the literacy coach did was knowing what teachers like first and knowing their teaching styles; presenting things in a way to catch teachers' interest; and being open with teachers. He further acknowledged that the literacy coach researched things before she presented them to teachers. According to the interview's analysis, the teachers and the literacy coach have highlighted the image that they are all comfortable with the literacy coach's support by being a part of their classrooms and teacher learning; therefore, the literacy coach needs to increase a collaborative spirit by building a good rapport between classroom teachers, students, and administrators. The structure could help teaching and learning be easier to both literacy coaches, students, teachers, and administrators. The connection can also promote change by setting goals for a literacy coach and all teachers, especially those teachers who think that they are alone in the field of teaching reading. 


\section{How did Two Teachers Learn Teaching Reading}

Feiman-Nemser (2001) suggested that teacher learning responsibilities include increasing subject matter knowledge; increasing understanding of students and their learning; and increasing the tools to study teaching in the contexts of practice. It also includes facilitating classroom discussion, and being familiar with various curriculum materials, instruction, models of teaching, learning from others, and types of assessments. As I analyzed teachers' interview responses about how they learned, all the suggestions Feiman-Nemser (2001) stated were practiced. Even though these teachers got their support differently, they both appreciated and acknowledged learning from the literacy coach. Teachers from this study preferred learning by seeing someone professional co-teaching and modeling the instruction, working in the room with them, and then offering them hands-on activities rather than attending professional development where they would be told things they did not understand.

Teachers from this study were also introduced to various new things like the Daily 5 approach, the running records, and Being-A-Writer. The strategy of modeling the lessons seems the favorite strategy the literacy coach used to support teachers to learn. It was noted as an essential observable and clear strategy teachers of this study acknowledge more than any other thing because it helped them relate themselves to what the literacy coach practiced to help increase the skills of teaching reading. The essential findings of this study that supported teachers learn how to teach reading includes the following:

- The literacy coach came into teachers' classroom, and co-taught with them,

- She modeled lessons while teachers watching the styles of practices,

- She provided them with the opportunities to practice instruction while they have been observed and got feedback immediately, 
- She helped them to practice new things like the Daily 5 approach, running records, and Being-A-Writer,

- She provided professional development,

- She encouraged them to learn from other teachers during the weekly small gradelevel groups of professional learning communities, and

- She influenced them to learn planning instruction using the students' interest.

- She researched literacy resources for teachers to use teach reading.

How teachers were supported and learned teaching reading, it extended my thought to a concept "literacy coach" as a primary skill architecture of teacher learning who puts teacher and students' learning in different backgrounds in the classrooms using individual discussion, and in the small grade level groups. Ball and Cohen (1999) stated that teachers needed to have advanced pedagogical knowledge and know how to make shifts in their teaching in responses to their students' learning.

According to interview responses, the literacy coach was able to provide teachers observable evidence that she used to support teachers understand the development of the student reading process and to modify teaching practices. Analyzing literacy coach and teachers’ interviews, indicated that the literacy coach provided support to teachers. In addition, Nancy, a novice teacher, learned more than Bob, an experienced teacher, because she spent the full year with the literacy coach learning getting support of how to teach reading in the classroom than Bob who reported that he had her last year three times. 


\section{Implications for Literacy Coach Support and Teacher Learning}

Although reading coaches may wear many hats, their primary goal activity is working directly with teachers in their classrooms. They model how to teach reading and writing lessons for teachers. They observe teachers teaching reading and writing activities and provide feedback immediately on their lessons. They assist and support teachers as they learn new reading instruction skills and techniques. They also support and guide classroom teachers while acting as mentors and assistants (Dole \& Donaldson, 2006, p. 486).

From the data collected, Mary, the literacy coach, understood the reading process and spent more of the coaching interactions with teachers in their classrooms, modeling the strategies, using the running records, implementing new things to teachers to increase the understanding of the reading process, and providing feedback to teachers' lessons. In addition, the International Reading Association (2004) suggested that the school districts hire individuals to be literacy coaches who have an in-depth knowledge of reading process, acquisitions, assessment, and instruction. In this study, there was no doubt that Mary had literacy coaching experience and had training at the university level.

Bean and Swan Degan (2012) stated that teacher's ultimate goal is to increase students learning and achievement, one of the main responsibilities of a coach is to support with that goal. The findings of this study support the growing theory regarding the usefulness of a literacy coach in each school. Therefore, the focus of the literacy coach needs to be on the support of teachers. Novice and experienced teachers need conceptual understandings of the literacy process as it develops for miscellaneous students. Bob and Nancy indicated their greatest areas of growth and learning from the literacy coach were on reading and writing because the areas were the greatest goals of the whole school.

From the interviews with the literacy coach, I learned that the most effective support is through going into teacher’s classroom, co-teaching and modeling the lessons for beginning 
teachers. To this point I definitely learned that the literacy coach needed to involve the administrators to help her to get access to all teachers' classroom and provide support to all teachers equally and follow up with experienced teachers just as she does with the beginning teachers. I suggest that the literacy coach with the support of the administrators could ensure that they organize a staff meeting at the end of each term, where all teachers will be provided with the opportunity in each grade level to give a presentation on how they taught reading or writing in their classroom, at the mean time the literacy coach listens their needs, and provides feedback to all teachers. This plan could provide the literacy coach and administrators an opportunity to determine whether the teacher had changed teaching reading that may have a positive influence on students’ learning.

\section{Summary and Recommendations for Further Research}

The purpose of this study was threefold. I examined how an elementary literacy coach supports teachers as they learn to teach reading in ways that meet the needs of their students. Second, I determined how the coaching influences the ways in which a classroom teacher plans for and carries out reading instruction. Finally, I understood how the educational context influences the nature of the coaching and how classroom teachers learn to teach reading. Therefore, the author of the current study developed recommendations for future research. The findings from this study recommend that the literacy coach could support teachers in various ways in perfecting new strategies that may result in higher student achievement. Both teachers from this study reported that the support of working with the literacy coach in their classrooms was provided collaboratively in all the areas of teaching reading and students' learning. With the support teachers got from the literacy coach, teachers recommend each school could have its own permanent literacy coach to help increase the knowledge of reading instruction and 
students’ achievement. The literacy coaches need to provide equal support to novice and experienced teachers, and teachers also need to work collaboratively to help increase teacher learning and student achievement.

Lyons and Pinnell (2001) stated that the goal of professional development is not to perfect an approach to instruction, but rather to promote ongoing learning. Listening to teachers’ responses from this study, to the explanation of their learning, and to the influences of a literacy coach, it was difficult to isolate the knowledge they learned from the literacy coach. Linda Darling-Hammond (1999) stated “teachers need to know subject matter deeply and understand how students think in order to create experiences that actually work to produce learning...we must transform instruction to ensure achievement (p. 2).” Therefore, to increase classroom teachers' learning and understanding of teaching reading, the literacy coach of this study used on-going professional development in the form of the traditional by talking, going into teachers’ classrooms, and presenting effective professional development of modeling instruction. Teachers were also given the opportunity to learn through implementing new things like the Daily 5 approach, Being -A-Writer, and running records in their classroom with the help of the literacy coach. Teachers acknowledged the way the literacy coach helped them to use their students’ needs or interests to teach reading and even provided students with various opportunities to articulate their text or share their own stories they wrote to their partners, to small or whole group in the classroom.

Through the support of the literacy coach, teachers of this study were able to expose students to different kinds of reading and writing. To indicate the understanding of the subject matter, Nancy was able to think of planning ahead for next year to introduce teaching her students to study the novel and practice the literature circle with her students. In addition, from 
the teachers' comments, I discovered that teachers are really active if they have knowledge of what they are supposed to teach, and they understand when they supposed to do it. Hence, as IRA (2004) recommended, the literacy coaches need to have a deep understanding and knowledge of literacy development to support teachers in the process of teaching reading.

Future research study is called for to investigate the changes in teachers' practices after supported by the literacy coach within the classrooms and measure the impact of the literacy coach on practices and student achievement. To build on the author's study of how the literacy coach supports teachers as they learn to teach reading to meet the need of all the students, the researchers can also look into these questions:

1. What kind of training is needed to help the literacy coaches know how to unlock the doors for all classroom teachers within the school to provide support to teach reading effectively?

2. Why do classroom teachers always close doors to coaching and find difficult to accept changes in the field of teaching reading, and how can they be encouraged to be involved in the process of continuing to learn about literacy development?

3. How do coaches and classroom teachers involved parents and community in supporting students’ literacy

Literacy coaches must be linked to all classroom teacher practices and students' achievement without any hesitation. Much research has been conducted about using literacy coaching in teaching and learning environment and the roles and responsibilities of the literacy coaches (Dole, 2006; Bean \& Swan Degan, 2012; Moxley \& Taylor, 2006; IRA, 2004; Walpole \& Blamey, 2008). However, there is a lack of research related to how literacy coaches might 
support teachers in improving their reading instruction to meet the needs of all students (Dole \& Donaldson, 2006; IRA, 2006; Deussen \& Buly, 2006; Vogt \& Shearer, 2007).

Therefore, the results of the study should be helpful in both literatures because the voices classroom teachers raised will be heard in the discussions of literacy coaches. The perceptions of the literacy coach can also provide insight on the basics of literacy coach discussions that would be most effective in the development of teacher learning and support on their instruction and on students' reading. Overall, the findings of this study indicated the importance of the literacy coach to teachers on helping them how to teach reading. The findings also indicated that going into teachers' classrooms with the knowledge of understanding their needs, co-teaching and modeling lessons while teachers are watching, are the most valuable approaches the literacy coach of this study used to increase teacher learning. Teachers also had acknowledged the support the literacy coach provided to them in their classrooms. 


\section{REFERENCES}

Al Otaiba, S., Hosp, J. L., Smartt, S., \& Dole, J. A. (2008). The challenging role of a reading coach: Acautionary tale. Journal of Educational \& Psychological Consultation, 18(2), 124-155.

Allington, R. L. (2002). What I've learned about effective reading instruction from a decade of studying examplary elementary classroom teachers. Phi Delta Kappan, 83(10), 740-74.

American Educational Research Association (AERA). (2005, Summer). Teaching teachers: Professional development to improve student achievement. Research Points, 3(1).

Association, A. E. (2005). Research points. Teaching teacher: Professional development to improve student achievement. Washinton, DC, 3(1).

Association, I. R. (2004). The role and qualifications of the Reading Coach in the United States. Newark, DE.

Association, I. R. (2006). Standards for Middle and High School literacy coaches, Newark,. Retrieved from http://www.reading.org/downloads/resources.

Ball, D. L., \& Cohen, D. K. (1999). Developing practice, developing practitioners: Toward a practice-based theory of professional education. In L. Darling-Hammond, \& G. Sykes, Teaching as the learning professional: Teaching as the learning professional: Handbook of pra (pp. 3-32). San Francisco: Jossey-Bass Inc.

Bean, R. (2004). Promoting effective literacy instruction: The challenge for literacy coaches. The California Reader, 37(3), 58-63. 
Bean, R. M. (2004). The reading specialist: Leadership for te classroom, school, and community. New York: The Guilford Press.

Bean, R. M. (2009). The reading specialist: Leardership for classroom, school, and community. New York, NY: The Guilford Press.

Bean, R. M., Swan, A. L., \& Morris, G. A. (2002). Tinkering or Transforming: A New paradigm for professional development for teachers of beginning reading. Paper presented at the Annual meeting of the American Educational Research Association. New Orleans, LA.

Bean, R. M., Swan-Dagen, A. L., \& Knaub, R. (2003). Reading specialists in schools with exemplary reading program: Functional, versatile, prepared. The Reading Teacher, 56(4), 446-455.

Bean, R., \& Swan-Dagen, A. (2012). Best practices of literacy leader: Keys to school improvement. New York, NY: Gildford Press.

Biancarosa, B., Bryk, A., \& Dexter, E. (2008). Assessing the value-added effects of literacy collaborative professional development on student learning. New York, New York: Paper presented at the 2008 Conference of the American Educational Research Association.

Blamey, K. L., Meyer, C. K., \& Walpole, S. (2008). Middle and high school literacy coaches: A national survey. Journal of Adolescent \& Adult Literacy, 52(4), 310-323.

Blase, J., \& Blase, J. (1999). Leadership for staff development: supporting the lifelong study of teaching and learning. Athens, GA: University of Georgia, College of Education.

Borko, H. (2004). Proffesional development and teacher: learning: Mapping the terrain. Educational Leadership, 57(8), 26-33. 
Borko, H., \& Putnam, R. (1996). Learning to teach. In D Berliner \& R Calfee (Eds),. In Handbook of researxh on educational psychology (pp. 673-699). New York, NY: Macmillan.

Borko, H., Davinroy, K. H., Bliem, C. L., \& Cumbo, K. B. (2000). Exploring and supporting teacher change: Two third-grade teachers' experience in a mathematics and literacy staff development project. The Elementary School Journal, 100(4), 273-306.

Buly, M. R., \& Valencia, S. W. (2002). Behind test scores: What struggling readers REALLY need. Australian Journal of Language and Literay, 27(3), 217-233.

Burkins, J. (2007). Coaching for balance: How to meet the challenges of literacy coaching. Newwark, DE: international Reading Association.

Carbo , M., \& Kapinus, B. (1995). Strategies for increasing achievement in reading. In Educational Everybody's children, edited by R.W. Cole (pp. 75-98). Alexandria, VA: Association for Supervision \& Curriculum Development.

Carlisle, J. F., Cortina, K. S., \& Katz, L. A. (2011). First-grade teachers' response to three models of professional development in reading. Reading and Writing Quarterly, 27(3), 212-238.

Cochran-Smith, M. (2001). The outcomes question in teacher education. Teaching And Teacher Education, 17, 527-546.

Cochran-Smith, M. (2003). Learning and unlearning: The education of teacher educatio. Teaching and Teacher Education, 19, 5-28. 
Cochran-Smith, M., \& Zeichner, K. (2005). Studying teacher education: The report of the AERA panel on research and teacher education. Mahwah,NJ: Lawrence Erlbaum Associates.

Cooper, J. (2007). Strengthening the case for community-based learning in teacher education. Journal of Teacher Education, 63(3), 245-255.

Cooter, K. S. (2003). Preparing middle school students for TAKS in writing: A professional development seminar. Paper presented at the meeting of North Texas Urban Educators, Fort Worth, TX.

Creswell, J. W. (1998). Qualitative inquiry and research design: Choosing among five traditions. Thousand Oaks, CA: Sage.

Creswell, J. W. (2007). Qualitative inquiry \& research design: Choosing among five approaches. Thousand Oaks, CA: Sage Publications, Inc.

Cunningham, P. M., \& Allington, R. L. (2006). Classroom that works; They can all read and write (4th ed.). Boston: Allyn \& Bacon.

Darling-Hammond. (1999). Educating teachers: The academy's greated failure or its not importand future? Academe, 85(1), 26-34.

Day, C. (1999). Development Teachers: The challenges of lifelong learning. London: Falmer Press.

Denzin, N. K., \& Lincoln, Y. S. (1994). Introduction: Entering the field of qulitative research. In N.K. Denzin and Y. S. Lincoln (Eds.), Handbook of qualitative research (2nd ed) (pp.117). Thousand Oaks, CA: Sage. 
Denzin, N. K., \& Lincoln, Y. S. (2002). Introduction:The dicipline and practice of qualitative research. In N.K. Denzin \& Lincoln (Eds.), Handbook of qualitative research (2nd ed) (pp. 1-28). Thousand Oaks, CA: Sage.

Desimone, L. M., Porter, A. C., Garet, M. S., Yoon, K. S., \& Birman, B. F. (2002). Effects of professional development on teachers' instruction: Results from a three-year longitudinal study. Educational Evaluation and Policy Analysis, 24(2), 81-112.

Deussen, T., \& Buly, M. R. (2008). Connecting coaching and improved literacy Northwest Education. Retrieved February 2, 2006, from http://www.nwrel.org/12-01/brief

Deussen, T., Coskie, T., Robinson, L., \& Autio, E. (2007). Coach can mean many things: Five categories of literacy coaches in Reading First. Issues \& answers. Institute of Education Science: Regional Educational Laboratory Northwest .

Diller, L. (1999). Opening the dialogue: Using culture as a tool in teaching young African American children. The Reading Teacher, 52(8), 820-828.

Dole, J. A. (2004). The changing role of the reading specialist in school refoem. The Reading Teacher, 57, 462-471.

Dole, J. A., \& Donaldson, R. (2006). What am I supposed to do all day? Three bid ideas for the reading coach. The Reading Teacher, 59(5), 486-488.

Domitrovich, C. E., Gest, S. D., Gill, S., Bierman, K. L., Welsh, J., \& Jones, D. (2009). Fostering high quality teaching in Head Start classroom: Experimental evolution of an integrated curriculum. American Education Research Journal, 46, 567-597. 
DuFour, R., Eaker, R., \& DuFour, R. (2006). On common ground: The power of professional learning. Bloomington, IN: Solution Tree.

Edwards, P. A., McMillon, G. T., \& Tuner, J. D. (2010). Change is gonna come; transforming literacy education for African American students. New York, NY: Teachers College Press.

Feiman-Nemser, S. (2001). From preparing to practice: Designing a continuum to strengthen and sustain teaching. Teachers College Record, 103(6), 1013-1043.

Foltos, L. (2007). Peer coaching: Changing classroom practice and enhancing student achievement. Utah Special Educator, 27(5), 34-37.

Frey, J. P., \& Kelly, P. R. (2002). The effects of staff development, modeling, and coaching of interactive writing on instructional repetoires of K-1 teachers in a professional develoment school. National Reading Conference Yearbook, 51, 176-185.

Fullan, M. (1991). "The best faculty of education in the country: A Fable" submitted to the Strategic planning committee. Faculty of Education: University of Toronto.

Fullan, M. (1993). Change forces: Probing the depths of educational reform. London: Falmer Press.

Gall, M. D., \& Renchler, R. S. (1985). Effective staff development for teachers: A researchbased model (ERIC). College of Education: University of Oregon.

Garet, M. S., Poter, A. C., Desimone, L., Birman, B. F., \& Yoon, K. S. (2001). What makes professional development effective? Results from a national sample of teachers. American Educational Research Journal, 38, 915-945. 
Gergen, K. J. (1994). Realities and relationhips. Cambridge: Harvard University Press.

Gersten, R., \& Morvant, M. (2006). Close to the classroom is close to the bone: Coaching as a means to translate research into classroom practice. Exceptional Children, 62, 52-66.

Goldhaber, D., \& Brewer, D. (2000). Does teacher certification matter? High school teacher certification status and student achievement. Educational Evaluation and Policy Analysis, 22(2), 129-145.

Grossman, P. (1990). The making of a teacher. New York: Teachiers College Press.

GrossmanP, Hammerness, K., \& McDonald, M. (2009). Redefining teaching, re-imagining teacher education. Teacher and Teaching: Theory and Practice, 15(2), 273-289.

Guba, E. G., \& Lincoln, Y. S. (1994). Competing paradigm in qualitative research. In N.K. Denzin and Y.S. Lincoln (Eds.), Handbook of qualitative research (pp. 1-17). Thousand Oaks, CA: Sage.

Guskey, T. (2002). Does it make a different? Evaluating professional development. Educational Leadership, 59(6), 45-51.

Gutierrez, K., Crossland, K., \& Berlin, D. (2001). Reconsidering coahing: Assisting teachers' literacy practices in the zone of proxiaml development. Paper presented at the meeting of the American Educational Reseach Association. Seattle, WA.

Hammerness, K., Darling-Hammond, L., \& Bransford, J. (2005). How teachers learn and develop world. In L. Darling-Hammond \& J. Brandsford (Eds.),. In Preparing teachers for a changing orld: What teachers should learn and be able to do (pp. 358-389). San Francisco: Jossey-Bass. 
Heilman, A. W., Blair, T. R., \& Ripley, W. V. (2002). Principles and practicesof teaching reaading (10th ed.). New Jersey: Pearson Education. In Upper Sadd River.

Hough, H., Bryk, A., Pinnell, G., Kerbow, D., Fountas, I., \& Scharer, P. (2008). Measuring changes in the practice of teachers engaged in literacy collaborative professional development: Preliminary results from a four year study. Paper presented at the 2008 conference of the American Educational Research Association. New York, New York.

Hsieh, H. F. (2005). Three approaches to qualitative content analysis. Qualitative Health Research, 15(9), 1277-1288.

International Reading Association. (2004). The role and qualification of the reading coach in the United States. Author.

International Reading Association. (2006). Standards for middle and high school coaches. Newark, DE: International Reading Association.

Joyce, B., \& Showers, B. (1996). Staff development as a comprehensive srvice organization. Journal of Staff Development, 17, 2-6.

Joyce, B., \& Showers, B. (1996). The eveolution of peer coaching. Educational Leadership, 53(6), 12-16.

Joyce, B., \& Showers, B. (2002). Student achiement through staff development. Alexandria, VA: Association for Supervision and Curriculum Development.

Kelleher, P. (2003). Professional development that works: A model for assessment-driven professional development. November 20, 2006. Retrieved from Questia database. 
Kennedy, M. M. (1991). Some surprising findings on how teachers learn to teach. Educational Leardership, p. 14-17.

Kennedy, M. M. (1999). The role of preservice teacher education. Darling-Hammond, L \& G Sykes (Eds.),. In Teaching as the learning professor: Handbook of policy and practice (pp. 54-85). San Francisco, CA: John Wiley \& Sons, Inc.

Knight, J. (2007). Instructional coaching: A partnership approach to improving instruction. Thousand Oaks, California: Corwin Press.

Kohler, F. W., Ezell, H. K., \& Paluselli, M. (1999). Promoting changes in teachers' conduct of student pair activities: An examination of reciprocal peer coaching. Journal of Special Education, 33(3), 154-165.

Lapp, D., Fisher, D., Flood, J., \& Frey, N. (2003). Dual role of urban reading specialist. Journal of Staff Development, 24(2), 33-36.

Lipson, M. I., Mosenthal, J. H., Mekkelsen, J., \& Russ, B. (2004). Building knowledge and fashioning success one school at a time. The Reading Teacher, 57(6), 534-542.

Lynch, J., \& Furguson, K. (2010). Reflections of elementary school coaches on practice: Roles and perspectives. Canadian Journal of Education, 33(1), 199-227.

Lyons, C., \& Pinnell, G. S. (2001). Systems for change in literacy education: A guide to professional development. Portsmouth, NH: Heinemann.

Marsh, J. A., McCombs, J. S., \& Martorell, F. (2010). How instructional coaches support datadriven desicion making: Policy implementtion and effects in Florida middle schools. Educational policy, 24, 872-907. 
Marsh, j., McCombs, J., Lockwood, J., Martoreel, F., Gershwin, D., Naftel, S., Crego, A. (2008). Supporting literacy across the sunshine state: A study of Florida middle school reading coaches. Santa Monica, CA: RAND Corporation.

McEachin, J, A, Dorman, B. C., Reed, K. H., Gillmore, V. D., \& Bray, K. M. (2006). Position Staement on the roles and qualification of literacy coaches in Florida. Orlando Florida: Florida Literacy Coaches Association.

Merriam, S. B. (1998). Qualitative research and case study application in education. San Francisco, CA: Jossey-Bass.

Mertler, C. A. (2003). Preservice versus inservice teachers' assessment literacy: Does classroom experience make a difference? Paper presented at te Annual meeting of the Educational Reseach Association. Columbus, $\mathrm{OH}$.

Miles, B. M., \& Huberman, M. A. (1994). qualitative data analysis: An expandend source book (2nd ed.). Newbury Park, CA: Sage Publications.

Morrow, L. M., O"Connor, E. M., \& Smith, J. K. (1990). Effects of strong reading program on the literacy development of at risk-kindergarten children. Journal of Reading Behavior, 22, 255-275.

Moxley, D. E., \& Taylor, R. T. (2006). Literacy coaching: A handbook for school leaders. Thousand Oaks, CA: Corwin Press.

Mraz, M., Algozzine, B., \& Watson, P. (2008). Perceptions and expectations of roles and responsibilities of literacy coaching. Literacy Research and Instruction, 47(3), 141-157. 
National Commission on Teaching and America's Future. (1996, Spetember). What mtters most: Teaching for America's future. New York: Author.

National Reading Panel. (2000). Report of the National Reading Panel: Teaching children to read. Bethesda, MA: National Institute of Children Health and Development.

National Staff Development Council. (2001). NSDC standards for staff development. Retrieved from http://www.nsdc.org/standards.

Neufield, B., \& Roper, D. (2002). Off to a good start: Year I of collaborative coaching and learning in the effective practice schools. Cambridge, MA: Education Matters, Inc.

Neuman, S., B, \& Cunningham, L. (2009). The impact of professional development and coaching on early language and literacy instructional practices. American Educational Research Journal, 46(2), 532-566.

Noguera, P. (2003). City schools and the American dream: Reclaiming the promise of public education. New York: Teachers' College Press.

Patton, M. Q. (2002). Qualitative Research and Evaluation Methods. CA:Sage: Thousand Oaks.

Pianta, R., Mashburn, A., Downer, J., Hamre, B., \& Justice, L. (2008). Effects of web-mediated professional development reseource on teacher-child interactions in pre-kindergarten classrooms. Early Childhood Research Quarterly, 23, 431-451.

Poglinco, S., Bach, A., Hovde, K., Rosenblum, S., Saunders, M., \& Supovitz, J. (2003). The heart of the matter: The coaching model in America's Choice schools. Pennsylvania: Consortium for Policy Research in Education: University of Pennsylvania, Graduate School of Education. 
Powell, D. R., Diamond, K. E., Burchinal, M. R., \& Koehler, M. J. (2010). Effects of an early literacy professional development intervention on head start teachers and children. Journal of Educational Psyco, 102(2), 299-312.

Puig, E., \& Froelich, K. (2007). The literacy coach: guiding; Guiding in the right direction. Boston, MA: Pearson Educatioal.

Quatroche, D. J., Bean, R. M., \& Hamilton, R. L. (2001). The role of the reading specialist: A Review of research. The Reading Teacher, 55, 282-294.

Reutzel, R. D., \& Cooter, R. B. (2012). The essentials of teaching children to read: The teacher makes the difference (3rd ed.). Boston: Pearson.

Ripley, A. (2008). Rhee tackles classroom challenge. Retrieved November, 2008, from http://www.time.com/time/magazine/article/.

Rodgers, A., \& Rodgers, E. (2007). The effective literacy coach: Using inquiry to support teaching and learning. New York: Teachers College Press.

Rodgers, A., \& Rodgers, E. M. (2004). Scaffolding literacy instruction: Strtegies for K-4 classrooms. Portsmouth, NH: Heinemann.

Rodgers, A., \& Rodgers, E. M. (2007). The effective literacy coach. New York: Teachers College Press.

Sailors, M., \& Price, L. R. (2010). Professional Development that support the teaching of cognitive reading strategy instruction. Elementary School Journal, 110(3), 301-322.

Sailors, M., Hoffman, J. V., Pearson, P. D., Beretvas, N. S., \& Matthee, B. (2007). Learning to read with READ: Testing the effectiveness of the "Learning for Living" project. In C. S. 
Mutua, (Eds.), Research on education in Africa, the Caribbean, and the Middle East (pp. 121-144). Greenwich, CN: Information Age Press.

Sailors, M., Hoffman, J. V., Pearson, P. D., Beretvas, N. S., \& Matthee, B. (2010). The effects of first and second language instruction in South African rural schools. Bilingual Research Journal, 33, 1-21.

Sanders, W., \& Rivers, J. (1996). Cumulative and residual effects of teachers on future student academic achievement. Knoxville: University of Tennessee, Value-Added Research and Assessment Center.

Seidman, I. (2006). Interviewing as qualitative research: A guide for researchers in education and the social sciences (3rd ed.). New York, NY: Teachers College Press.

Shulman, L., \& Shulman, J. H. (2004). How and what teachers learn: A shifting perspective. Journal of Curriculum Studies, 36(2), 257-271.

Slavin, R. E., Cheung, A., Groff, C., \& Lake, C. (2008). Effective reading programs for middle and high schools: A best-evidence synthesis. Quarterly, 43(3), 290-322.

Snow, C. E., Burns, S. M., \& Griffin, P. (1998). Preventing reading difficulties in young children. Washington, DC: National Academy Press.

Steckel, B. (2009). Fullfilling the promise of literacy coaches in urban schools. What does it take to make an inpact? The Reading Teacher, 63(1), 14-23.

Sturtevant, E. G. (2003). The literacy coach: A key to improving teaching and learning in secondary schools. Retrieved from http;//www.all4ed.or/publication_material/reports. 
Symonds, K. W. (2003). Literacy coaching: How school districts can support a long-term strategy in a short-term world. Retrieved from http://www.basrc.org/Pubs\&Docs/LiteracyCoaching.pdf.

Tallerico, M. (2005). Supporting and sustaining teachers' professional development: A principal's guide (pp. 54-630). Thousand Oaks, CA:: Corwin.

Taylor, B. M., Pearson, P. D., \& Rodriguez, M. C. (2005). The CIERA school change framework: An evidence-based approach to professional development and school reading improvement. Reading Research Quartely, 40(1), 40-69.

Taylor, B., Pearson, P., Peterson, D., \& Rodriguez, M. (2005). The CIERA school change framework: An evidence-based approach to professional development and school reading improvement. Reading Research Quarterly, 40(1), 40-69.

Taylor, R. T., Moxley, D. T., Chanter, C., \& Boulware, D. (2007). Three techniques for successful literacy coaching. Principal Leadership (Middle School Edition), 7(6). Retrieved from WilsonWeb Database.

Timperley, H. P. Coaching through feedback: A close and critical analysis. Paper presented at the American Educational Research annual meeting, New York, . Retrieved March 2428, 2008, from http://www.instep.net.nz/about_this_site/accessibility/case_1_coach.

Toll, B. (2005). Literacy coach's survival guide: Essential questions and practical answers. Newark, DE: International Reading Association.

Van Keer, H., \& Verhaeghe, J. P. (2005). Comparing two teachers development programs for innovating reading comprehension with regard to teachers' experiences and student 
outcomes. Teaching and Teacher Education: An International Journal of Research and Studies, 21, 543-562.

Veenman, S. E., Denessen, J., Gerrits, J., \& Kenter, J. (2001). Evaluation of a coaching program for cooperating teachers. Educational Studies, 27(3), 317-340.

Vogt, M. E., \& Shearer, B. A. (2007). Reading specialists and literacy coaches in the real world (2nd ed.). Boston, MA: Pearson.

Vygotsky, L. (1978). Mind and Society: The development of higher mental processes. Cambridge: MA: Harvard University Press.

Walls, R., Nardi, A., Von Minden, A., \& Hoffman, N. (2002). The characteristics of effective and ineffective teachers. Teacher Education Quarterly, 29, 39-48.

Walpole, S., \& Blamey, K. L. (2008). Elementary literacy coaches: The reality of dual roles. The Reading Teacher, 62, 222-231.

Walpole, S., \& McKenna, M. C. (2004). The literacy coach's Handbook: A Guide to Research Based practice. New York:: Guilford.

Walpole, S., \& McKenna, M. C. (2004). The literacy coach's handbook:A guide to researchbased practice. New York: The Guilford Press.

Wei, R. C., Darling-Hammond, L., Andree, A., Richardson, N., \& Orphanos, S. (2009). Professional Learning in the learning profession: A status report on teacher development in the United States and abroad. Dallas,TX: National Staff Development Council.

Wold, L. S. (2003). An examination of teachers' "learning to act reflectio". Reading Research and Instruction, 42(3), 52-74. 
Zeichner, K. (2000). Ability-based teacher education: Elementary teacher education at Alverno College. In L. Darling -Hammond (Ed.), Studies of excellence in teacher education: Preparation in the undergraduate years. Washington, DC: National Commision on Teaching and America's Future: American Association for College of Teacher Education.

Zeichner, K., \& Melnick, S. (1996). The role of community field experiences in preparing teachers for cultural diversity. In K Zeichener, S Melnick, M L Gomez (Eds.). In Currents of reform in preservice teacher education (pp. 176-196). New York, NY: Teachers College Press.

Zimmerman, J. (2006). Why some teachers resist change and what principals can do about it. National Association of Secondary School Principals Bulletin, 90(3), 238-249. 


\section{Appendix A}

\section{First Interview Questions for Literacy Coach}

Interviewee:

Place:

Date:

Time:

1. Explain in detail your professional background including number of years teaching.

2. Describe the coaching activities you engage in to support teachers in improving reading and literacy instruction (modeling, one-on-one teacher collaboration, group meetings, coplanning, co-teaching, teacher's observation, providing feedback, etc.).

3. How do you make your decisions about how you support teachers as they teach reading? Probes:

- What influences your coaching in classroom teachers' planning?

- What influences your coaching in reading instruction?

- Are there particular materials you use?

- Do you feel state/district influences on your support of coaching to teach reading?

4. What is your experience of working in your school?

Probes:

- Describe your teachers.

- What are some of the concerns of the teachers as they learn to teach reading?

5. Describe the role of the literacy coach in this school Probes:

- Describe the experience support you have provided for your teachers and the rationale in coaching.

- What professional development have you provided to teachers this year to help them understand how to teach reading and how to improve their reading instruction?

- How do you decide which professional development training should be offered to the teachers?

- What do you find challenging in supporting teachers as a coach? Why? 
- What do you do when one of your teachers experiences difficulties teaching reading?

- What do you do as a coach to promote your knowledge of supporting teachers?

- When considering your work as a literacy coach, how could you describe your relationship with the staff/teachers?

6. How do you think your coaching is going?

Probes:

- What are some of your challenges as a literacy coach?

- Do you feel like a successful literacy coach?

- Are there things you know now about teaching reading that you didn't at the beginning of your literacy coaching?

7. Describe instruction/methods that can be used to teach students to read. Do they work? How?

8. Is there any additional information that I should know that will help me understand how literacy coaches support teachers' learning?

9. Do you have any questions for me? 


\section{Appendix B}

\section{Second Interview Questions for Literacy Coach}

Interviewee:

Place:

Date:

Time:

1. R: How do you support teachers to understand the process of teaching reading?

Probes:

- Do they indicate cooperation to your support?

- What does your professional development look like in this school? How do you do them?

- What is important in professional development at this school?

- What do you expect from your teachers?

- How do you know your teachers are progressing in teaching reading?

- Are there things/ways you would like to be coaching to teach reading but aren't there yet? Why?

2. How is the reading performance of the students in this school?

Probes:

- How did you decrease the failure or increase the success of teaching reading?

3. Describe your role in supporting a teacher on her reading instruction.

Probes:

- What is the most difficult aspect of your role as a literacy coach?

- Do you see differences in teachers' reading instruction between the preservice and experienced teachers?

- What is important in supporting reading instruction at this school?

4. What will you change in the support of teaching reading in the future? Why?

5. How has your support of teaching reading gone for you in the past months? Probes:

- How do you think of yourself as a successful literacy coach?

- How do your teachers collaborate during the support of teaching reading? 
- Are there things that you do in your support that can influence you and your teachers in the process of teaching reading?

- What have you done to help support teachers who struggle teaching reading in the past months?

- What have you done to elp students who struggle with reading and challenge more skilled readers>

- Do you consider yourself a successful literacy coach in this process?

6. Review of goals from beginning of the literacy coach. Have you been able to move forward on the support? Why/ Why not?

7. What do you hope to keep the same in your support of teaching reading for next year? Why?

8. What will you change in your support of teaching reading /reading instruction? Why?

9. Is there anything to influence you from making those changes?

10. What will your teachers say if asked what they will remember about teaching reading in your school?

Do you have any question? Thank you so much. 


\section{Appendix C}

\section{First Interview Questions for Teachers}

\section{Interviewee: \\ Place: \\ Date: \\ Time: \\ INTERVIEW ONE}

1. R: Describe your background including how many years have you been teaching; your qualifications and current grade level of instruction.

Probes:

- What was your reason for becoming a teacher?

2. What did you learn about the teaching of reading?

Probes:

- What did your cooperating teachers/supervisor do to help you think about the teaching of reading?

- What do you think most prepared you for teaching reading?

- What was most helpful in your teaching reading at this school?

3. How is the reading performance of the current group of students you have in this class? Probes:

- Do you think that you have been successful teaching this group of students? Why? /Why not?

- What kind of instruction/methods do you use to them?

4. Describe the role of the literacy coach.

Probes:

- How often do your literacy coach provide support in your classroom?

- When she visited you, what would be the focus of your interactions with her?

- Do you see any difference or improvement after you got the support from the literacy coach? How about with other teachers in the same grade level? 
- Does the literacy coach provide support with increasing literacy-reading performance of students? If so, how/how not?

- Describe the role of the literacy coach that has greatest influence on your teaching reading /reading instruction.

5. How do you think your teaching of reading is going?

6. R: Explain your experiences working with the literacy coach. Probes;

- What have you learned?

- What are your main successes in learning to teach reading?

- Describe your concerns or problems you have when meeting the literacy coach in this school.

- Do you think that is useful to have a literacy coach in each school and why or why not?

- If you could to design an effective professional development with the literacy coach, what would you include?

- Is there anything that I should know about the coaching experience the literacy coach has in this school?

7. Describe how you get opportunities for professional development in literacy in this school.

8. Is there any additional information that I should know that will help me understand how literacy coaches support teachers' learning? 


\section{Appendix D}

\section{Second Interview Questions for Teachers}

Interviewee: ................. Place: ............. Date:

Time:

1. Explain what you learned while working with the literacy coach. Answered in $1^{\text {st }}$ interview

Probes:

- What has been helpful about the support experiences provided by the literacy coach?

- Explain the challenges you encountered while working with the literacy coach during coaching.

- How often do you get professional development?

- What particular features of professional development have been most helpful to you? What aspects have been less helpful to you?

- How do you think the professional development can be modified to make teaching easier for teachers?

2. How has your teaching change after you worked with the literacy coach?

Probes:

- What are your learning from the coaching? And why do you think that you are learning?

- During your teaching experiences in this school, did you learn anything about teaching reading? Did you learn anything about students? Did you learn anything about other teachers?

3. After getting opportunities of coaching, do you think your reading instruction improved to meet the needs of all the students? If yes, how? /If no, why? Probes:

- Describe one particular area of reading that most of your students struggle with? 
- Did you ever have any interaction with your literacy coach about this problem?

- What specific reading strategies have the literacy coach suggested for you to use? Are they working? Why/why not?

4. How do you make your decisions about how you teach reading?

- What influences your planning?

- What influences your reading instruction?

- Are you teaching reading the way you want to be teaching reading?

- What other things influence your teaching?

- Are there things/ways you would like to be teaching but aren't there yet? Why?

5. How have your years of teaching reading gone for you?

- How do you think of yourself teaching reading in this school?

- How do you think of yourself teaching reading to your students?

6. How can you define literacy coaching at this school?

- What would you like to see her teacher support?

- Do you consider yourself as a successful teacher of reading? Why/Why not?

7 Review the support you got this year. Have you been able to move forward on teaching reading successfully? Why/why not?

8.What do you hope to keep the same in your teaching of reading for next year? Why?

9. What will you change in your reading instruction in the future? Why?

10. Is there anything that prevents you from practicing good reading instruction in your classroom? 


\section{Appendix E}

\section{Approval Letter from the School Principal}

April 20, 2016

To Whom It May Concern:

We welcome Mohlanhledi Makumbila to work with our staff at Elementary School on her current research project. We understand that this research will not directly involve students but specifically our Academic Coach and teachers she works with.

Thank you, 


\section{Appendix F}

Dear Participant,

This letter is a request for you to take part in a research project to understand how an zlementary literacy coach supports teachers as they learn to teach reading in ways that meet the needs of their students and how a literacy coach and the classroom teachers who were coached experienced the coaching sessions designed to problematized and improve the practices of the slassroom teachers. This project is being conducted by Mohlanhledi Makumbila, MA in the Department of Curriculum and Instruction at WVU with supervision of Dr. Sharon Hayes, an associate professor, Elementary Education in the College of Education \& Human Resources, for a Doctoral Degree in Curriculum \& Instruction/Literacy. Your participation in this project is greatly appreciated. The interviews will take approximately 60-90 minutes and will be recorded.

Your involvement in this project will be kept as confidential as legally possible. All data will be kept safe in my locked locker in my house. I will not ask any information that should lea sack to your identity as a participant. Your participation is completely voluntary. You may skip any question that you do not wish to answer during the interviews and you may discontinue at any time during the process. Your class standing will not be affected if you decide either not to jarticipate or to withdraw. West Virginia University's Institutional Review Board acknowledgement of this project is on file.

I hope that you will participate in this research project, as it could be beneficial in roviding the insight into the nature and influence of this relationship on teaching teacher earning and student learning. Thank you very much for your time. Should you have any juestions about this letter or the research project, please feel free to contact Mohlanhledi Makumbila at (304) 216-2462 or by e-mail at mmakumb1@ mix.wvu.edu 


\title{
Appendix G
}

\author{
Office of Research Integrity and Compliance \\ B86 EMESNUT RHOGE RUAO MORGANTOWN WV 20506
}

\section{Acknowledgement Letter Exempt Initial Protocol Review}

\author{
Action Date \\ $04 / 27 / 2016$ \\ To \\ Sharon Hayes \\ From \\ Approval Date \\ Expiration Date \\ $04 / 27 / 2016$ \\ $04 / 26 / 2019$ \\ Subject \\ Acknowledgement Letter Exempt Initial Protocol Review \\ Protocol Number \\ 1604085717 \\ Title \\ Understanding how a literacy coach support teachers as they lean to teach \\ reading. \\ The above-teferenced study was reviewed by the Institutional Review Board IRB and \\ vas granted exemption in accordance with 45 CFR 46.101. \\ - In order to be considered human subject research, individually identifiable private information must be \\ obtained or used in the research. If there is no individually identifiable private information involved, the \\ project is not human subject research and does not require being submitted to the Office of Research \\ Integrity \& Compliance. Private information must be individually identifiable (i.e., the identity of \\ the subject is or may be readily ascertained by the investigator or someone else associated with the \\ information) in order to constitute research involving human subjects.
}

locuments reviewed and/or approved as part of this submission:

4212016135329.pdf: 2016-04-21-04:00

4212016135344.pdf: 2016-04-21-04:00

iteracy Coach and Teachers' Interview Questions.pdf: 2016-04-2!-04:00

locuments for use in this study have been acknowledged and are avaitable in the system in the Notes ad Attachments section of your protocol 


\section{Appendix $\mathbf{H}$}

\section{Sample Transcription Interview with the Literacy Coach}

\section{INTERVIEW TWO FOR LC}

Interviewee: Leslie $2^{\text {nd }}$ interview Place: Eastwood elementary/Leslie's office

Date: 5/23/16 Time: 11 a.m -12 noon

1. R: How do you support teachers to understand the process of teaching reading?
Aslaing pobod their problen

- L: OK first I you know I find out where they are in the process. I think as we talked earlier last week everybody's on a different starting point. So depending on

Collaborative where they're at that's I would begin with them. We do a lot of books studies enaet

based on en ifferent.

feachers' need 5 here. So sometimes it's working with the book study. Sometimes it is talking based on about just different techniques that they're using with the kids for the stages of students' level a grads reading that they're in. It also depends on the grade level they teach and the makeup of their classroom.

Probes:

R: Do they indicate cooperation to your support? the teachos' needs

L: Yes, for the teachers who want to help, they are very cooperative. Now there are some teachers that have not reached out to me for help so you know I guess you could say maybe they're reluctant to learn or to change maybe things that

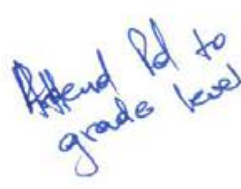

they've been doing. However, I am able to reach them when I provide

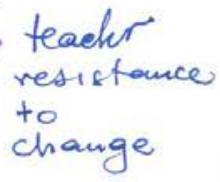

professional development to grade levels or to the school in that avenue. I reach everybody because everyone's in attendance at those so it can be either a whole group process or it can be more individualized.

- R: What does your professional development look like in this school? How do you do them?

$\mathrm{R}$ : What is important in professional development at this school?

- L: For the last two years we've really focused on writing because that was an area of weakness for our school so that has been our big focus for the last two years, but we also focused a lot on guided reading this year. And every teacher had either myself or someone from the county come in and model guided

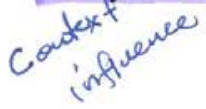


teachers and I can kind of just let them do that. But I know that's not the right answer. That would be my area I like the older kids where I can read really rich books and getting to great conversation. So the kindergartners are just a little squirrely. upredictable

2. R: How is the reading performance of the students in this school?

L: According to state wide tests. It varies amongst each grade level. So we have a percentage there that we can look at. It's not where I would like for it to be, but I think we've made progress over the last two years. I can tell you more after we finish our benchmark assessments because that is what we're in the process of doing right now I would say fifty percent of our kids approximately fifty percent of our kids are on level fifty percent or more are on level.

$$
\begin{aligned}
& \pm 5 \% \text { are } \\
& \text { on level }
\end{aligned}
$$

Probes:

R: How did you decrease the failure or increase the success of teaching reading?

L: I think having the professional development for guiding reading this year has $\mathrm{Pdft}_{+}$
been huge that's helped increase reading levels. I think adding in the benchmark assess ments assessments. Teachers have a more accurate way to assess whether their kids are moving in reading or not so I think that that definitely has helped to increase

3. R: Describe your role in supporting a teacher on her reading instruction.

$$
\text { find out the problem in class }
$$

L: Again I would meet with her and ask her where she felt she needed help, and find out pooblen ho felt about teaching reading and then I would come in in model lessons lepending on about the of ther. I would model either a guided readinglesson or on my model a whole tue st ewel reading

group lesson model a particular strategy for that particular teacher and spend you

know a good amount of time in there with her kind of gradual release of collaboratwe co- teach together

responsibility. We do, and then she would do, so that that's how I do that. I would

push into her classroom and actually do a guided reading group with a group of her students and she would sit there with me and watch and I might do that for a

couple of days and then she would turn around and do the guided reading and I 


\title{
Appendix I
}

\section{Sample Transcription Interview for Teachers}

\author{
INTERVIEW QUESTIONS FOR TEACHERS
}

Interviewee: Lana's and Marcus I $^{\text {st }}$ Place: Eastwood Elementary Date: 5/12 \& 13/16

Time: 1:45p.m - 2:50p.m

$$
\text { INTERVIEW ONE }
$$

1. R: Describe your background including how many years have you been teaching; your qualifications and current grade level of instruction.

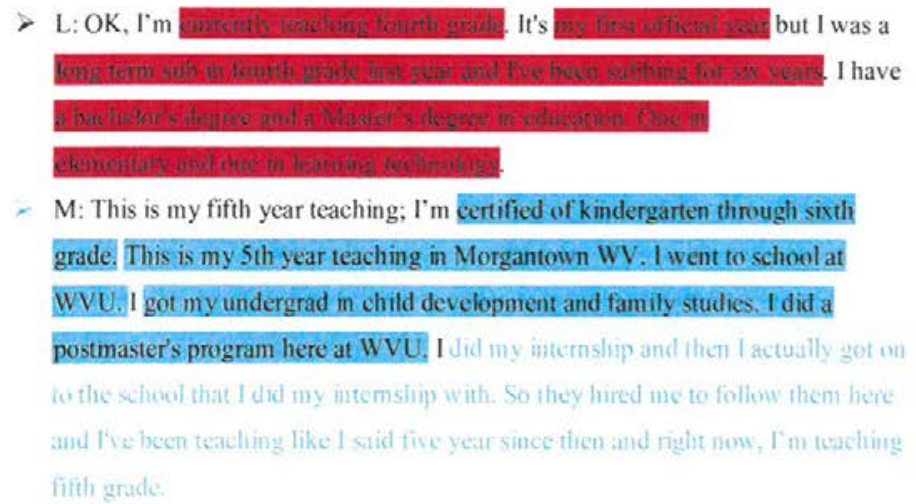

Probes:

$\mathrm{R}$ : What was your reason for becoming a teacher?

L: I wanted to be a teacher since I was probably in second grade watching my teachers and sceing what they were doing it was just always what I wats going to do consider anything else:

Commented [mm1]: Reason for being a teacher

M: Working with the kids. I've always done like football camps and sporting camps and then to me it's kind of the same thing, so just really working with the kids. 
2. R: What did you leam about the teaching of reading?

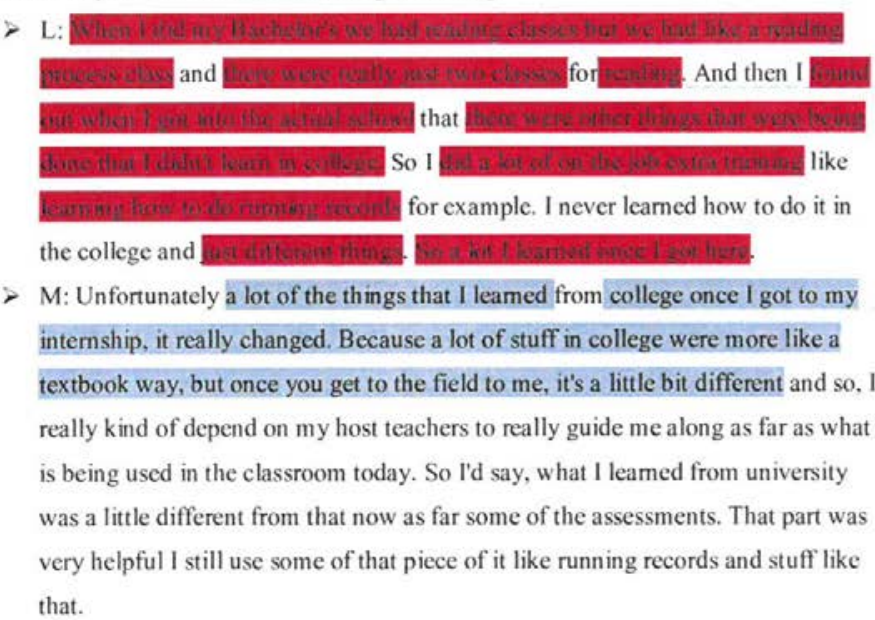

R: What did your cooperating teachers/supervisor do to help you think about the teaching of reading?

D: She was a huge help to me last year as a long-tenm sub in fourth grade. She got me into doing the Daily 5 approaches and she came into my room a couple times a week and helped me run the workshop because it's a station and workshop and got it all set up. She help me figure out how to run the stations and how to group the kids, just launched the whole thing right there in my room with me, and then. once we got it launched, she came less and less until I was on my own but she set me up with that big time. She also you know the running records and how to do that.

M: Leslie really open my eyes as opposed to trying new things and she does a really good job of researching different ways of doing stuff. She's pulling from other teachers and just presenting a way that is really encouraging to try. One of the things that we've used that's really stuck to me, for reading our Daily 5 Café and it's just a way to get the kids to exposure to more reading, more writing, look

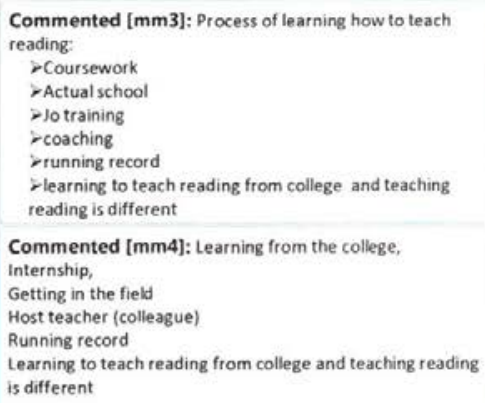

Commented [mm5]: Collaborative

Commented [mm6]: Daily 5 approach

Commented [mm7]: Provide professional development

Commented [mm8]: Problem solving

Commented [mm9]: Enacting the reading strategies

Commented [mm10]: Scaffolding herself from teaching reading

Commented [mm11]: Motivating to try new things Commented [mm12]: Searching reading information to differentiate instruction

Commented [mm13]: Use previous information from other teachers

Commented [mm14]: Modeling reading instruction to increase understanding

Commented [mm15]: Description of Daily 5 


\title{
Appendix $\mathbf{J}$
}

\section{Sample Matrix for Research Questions, Findings and Themes}

\author{
Findings
}

learnt:

- About changes of teaching reading between what she learnt from the course work and fieldwork

- How to do the running records

- How to integrate the Daily 5 approaches in her teaching reading

- How to run the workshop stations

- How to group the kids

- How to launched the reading program

- How to collaborate with other teachers

- Enacting how to teach reading

- How to solve the problem

- How to plan reading instruction based on students' interest

- How to let students with freedom of choice in terms of teaching reading

- How to model reading to students

- How to conference with the kids and check if they're progressing individually

- How to co-teach o

- Giving students' choices

- Guided reading approach and its different strategies

- Fierer Minger learnt:

- The changes of teaching reading from the college level and fieldwork

- How to try new things through the motivation of academic coach

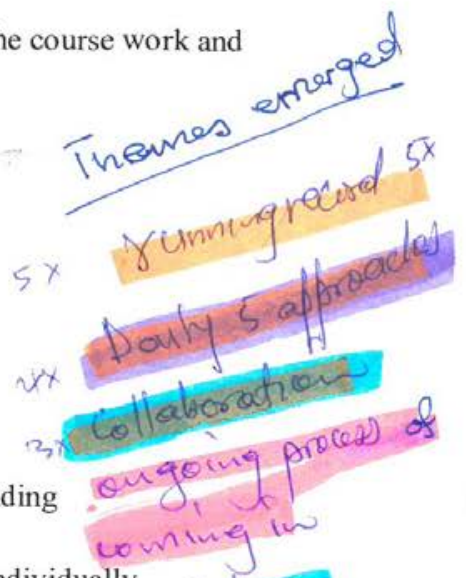

- How to integrate the Daily 5 approaches in the teaching reading

- How to do the running records

- How to co-teach

- How to reflects on students' data to adjust his reading instruction $\nless$

- How to plan reading instruction based on students' interest of

- Giving students more reading and writing opportunities

- How to provide students with freedom of choice in terms of teaching reading

How does an elementary literacy coach, support teachers as they learn to teach reading in ways that meet the needs of their students?

\section{Itings support}

- Through providing support on how to implement the Daily 5 approaches

- By searching resources and previous work from other teachers

- By searching for different ways of teaching reading and writing for them 
- By providing embedded professional development

- Modeling how to do the running records

- Working with students

- Visiting Lana's classrooms couple times to come and,

- Modeling how to group the students

- How to figure out how to run stations

- How to launched the teaching program

- How to collaborate together in terms of teaching reading

- Enacting reading instruction while watching

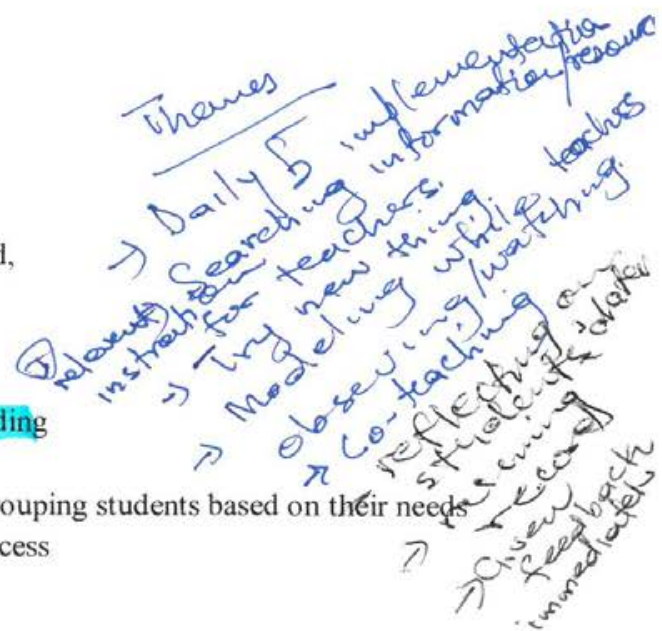

- How to solve the problem of teaching reading and grouping students based on their needs

- By bringing other teachers' work to her teaching process s' support

- How to get the kids to exposure to more reading, and more writing.

- How to try new things through the motivation of academic coach

- How to integrate the Daily 5 approaches in his teaching reading,

- How to do the running records $x$

- How to co-teach 2 .

- By presenting/modelling the lesson while

- Observing her

- By searching reading resources for us to increase our knowledge

- Proviral envacelea pal.

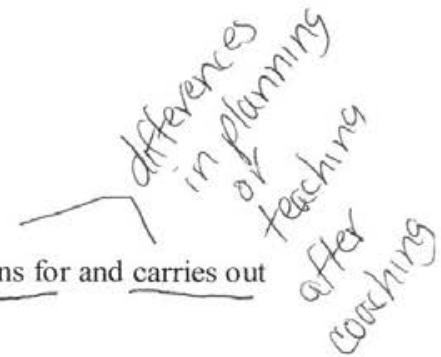

How does the coaching influence the ways in which a classroom teacher plans for and carries out reading instruction?

\section{sing influence for planning}

- Introducing the Daily 5 approaches within the school

- Through the enact instruction

- The whole school is doing Daily 5 approach

- Ongoing learning between the students and teachers within the school

- Through weekly ongoing professional development

- Collaborative and co-teaching approaches 6

- Scaffolding instruction based on teachers 'or students' needs

- Observing other teachers and doing practically

- Learning from other colleagues' work

- Getting support and feedback

- Students' growth in their reading levels and their interaction and how they articulate their text

- Looking within the adopted text

- Her students' progress 
- Working with small groups

- Giving students a choice $\checkmark$ influence for planning

- From his host teacher and a pacing guide

- The use of students' data

- Some of the assessment pieces learnt from the college helped him to

- Understand the coaching of how to do the running records $\ell$

- Searching different ways of doing stuff

- Pulled from other teachers

- Presenting a way that is encouraging to try

- Daily 5 approaches W

- Seeing what other teachers are doing in their classrooms

- The whole school is doing Daily cafe approach

- Using students' data to plan reading strategies

- Attending the professional learning communities

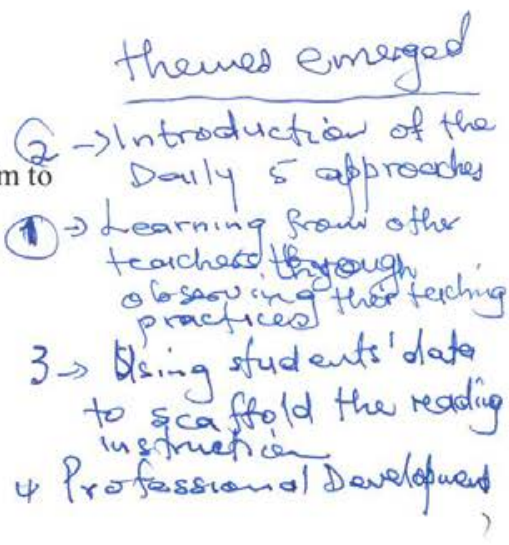

How does the educational context influence the nature of the coaching and the ways in which

Aclassroom teachers learn to teach?

influence:

- Adapted text

- Extra job training

- coursework

- Students interes $K$

- Going on in the outside world like current events about how to teach reading

- Professional development

influence:

2)

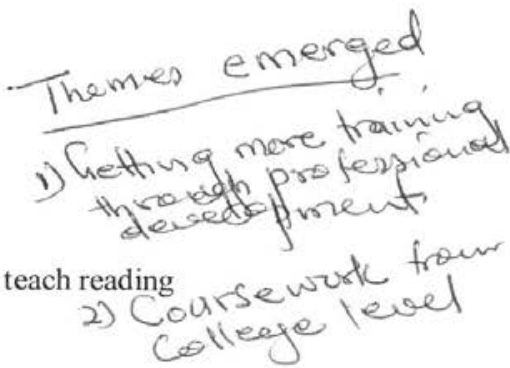

- School administration opportunities and freedom to try new things $\Varangle$

3)

- Academic coach neutrality helps us out when we struggle and want to try something new

- Pushed out more from the county

- Teaching experiences

- College knowledge

- fieldwork

- Literacy coach knowing our needs

- Professional development 